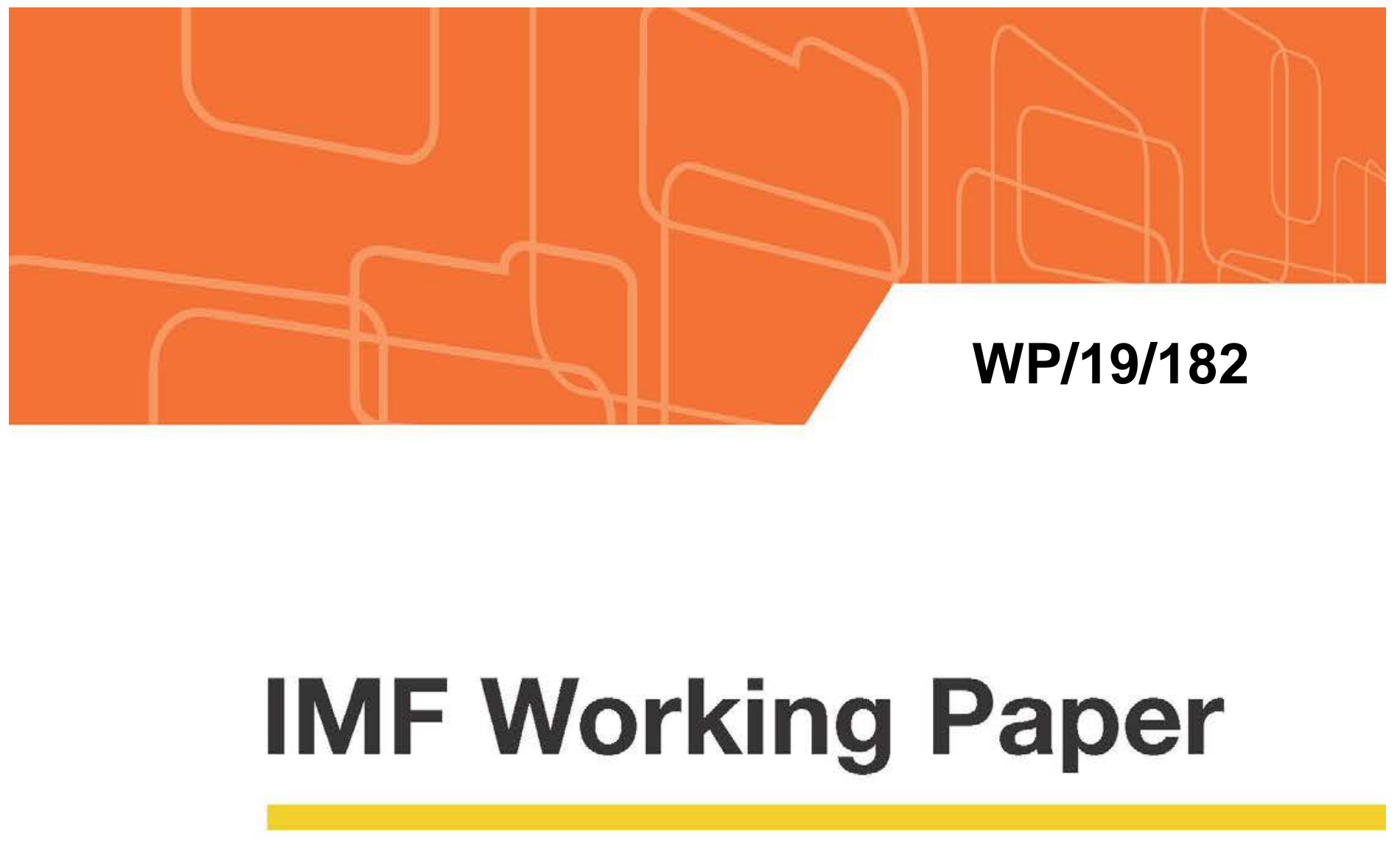

\title{
Debt Service and Default: Calibrating Macroprudential Policy Using Micro Data
}

by Erlend Nier, Radu Popa, Maral Shamloo, and Liviu Voinea

IMF Working Papers describe research in progress by the author(s) and are published to elicit comments and to encourage debate. The views expressed in IMF Working Papers are those of the author(s) and do not necessarily represent the views of the IMF, its Executive Board, or IMF management. 


\title{
IMF Working Paper
}

Monetary and Capital Markets Department

\section{Debt Service and Default: Calibrating Macroprudential Policy Using Micro Data1 Prepared by Erlend Nier, Radu Popa, Maral Shamloo and Liviu Voinea}

Authorized for distribution by Gaston Gelos

August 2019

\section{IMF Working Papers describe research in progress by the author(s) and are published to elicit comments and to encourage debate. The views expressed in IMF Working Papers are those of the author(s) and do not necessarily represent the views of the IMF, its Executive Board, or IMF management.}

\begin{abstract}
We provide empirical evidence to support the calibration of a limit on household indebtedness levels, in the form of a cap on the debt-service-to-income (DSTI) ratio, in order to reduce the probability of borrower defaults in Romania. The analysis establishes two findings that are new to the literature. First, we show that the relationship between DSTI and probability of default is non-linear, with probability of default responding to increases in DSTI only after a certain threshold. Second, we establish that consumer loan defaults occur at lower levels of DSTI compared to mortgages. Our results support the recent regulation adopted by the National Bank of Romania, limiting the household DSTI at origination to 40 percent for new mortgages and consumer loans. Our counterfactual analysis indicates that had the limit been in place for all the loans in our sample, the probability of default (PD) would have been lower by 23 percent.
\end{abstract}

JEL Classification Numbers: E51, E58. G21, G28

Keywords: Macroprudential policy, Household credit, Romania

Authors’ E-Mail Addresses: ENier@imf.org, Radu.Popa@bnro.ro, MShamloo@imf.org, Liviu.Voinea@bnro.ro

\footnotetext{
1 The views expressed here are those of the authors and do not necessarily represent the views of the IMF, its Executive Board, or IMF management, or of the National Bank of Romania. We are grateful to Florian Neagu and colleagues from the Financial Stability Department of the National Bank of Romania, and to the participants at the joint NBR-IMF Financial Stability Seminar held in Sinaia, on November 15th, 2018. This paper is the culmination of an analysis originally conducted jointly by IMF and NBR staff in the context of Romania Financial Sector Assessment Program (FSAP) 2018.
} 


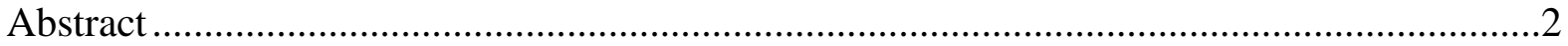

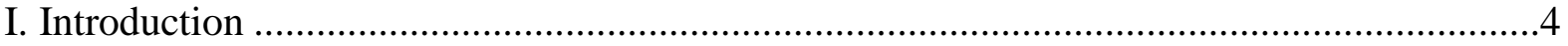

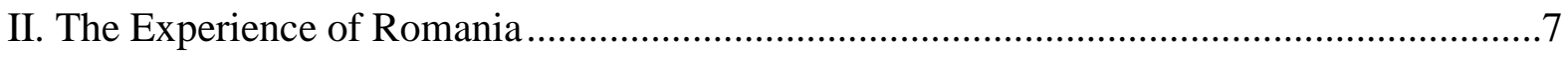

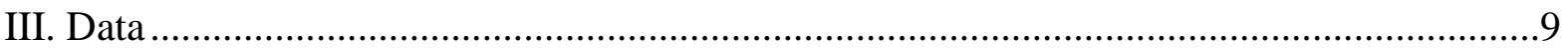

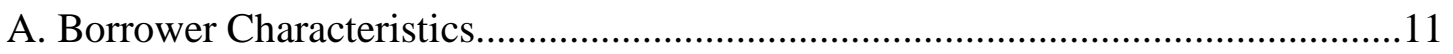

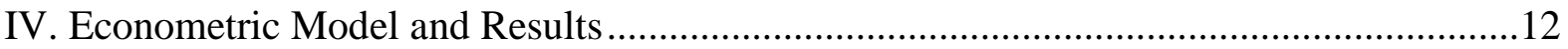

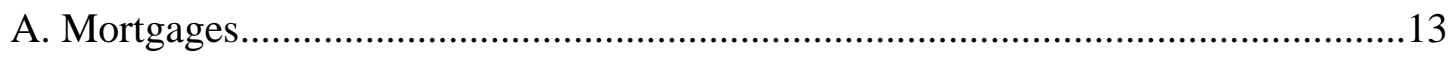

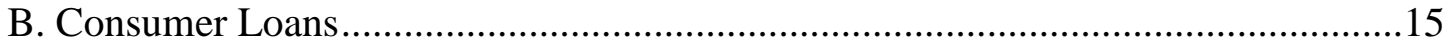

V. New NBR Regulations on DSTI Limits ...................................................................17

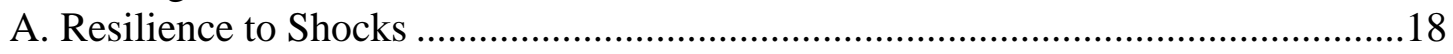

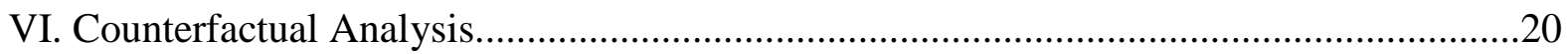

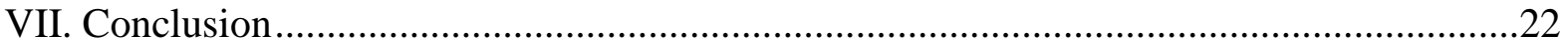

Tables

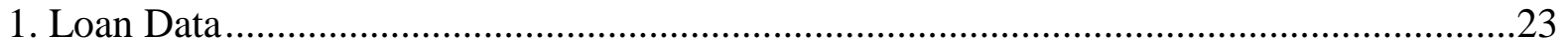

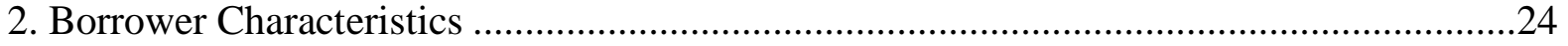

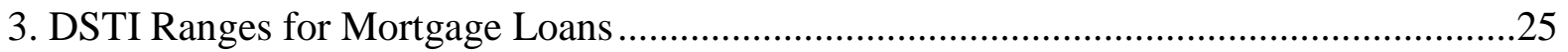

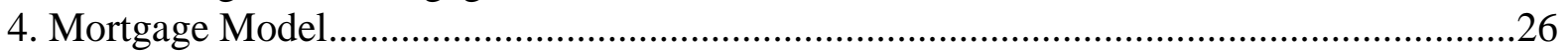

5. Mortgage Model - Marginal Effects.....................................................................27

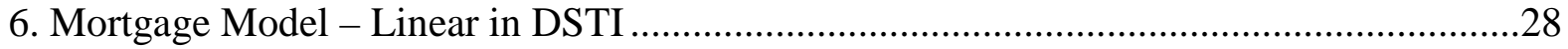

7. Mortgage Model - including debtors with multiple loans ..............................................29

8. Mortgage Model - Marginal Effects: including debtors with multiple loans.....................30

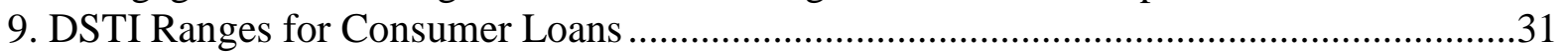

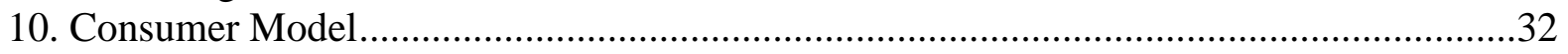

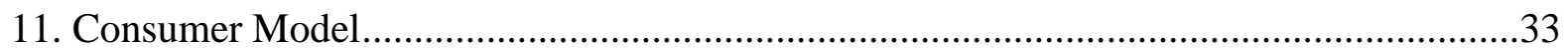

12. Shock Absorbency of a Loan Originated at DSTI of 40 percent....................................33

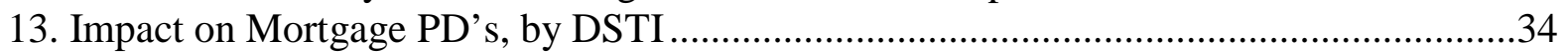

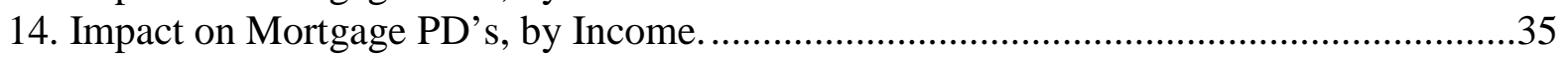

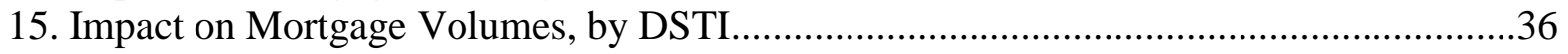

16. Impact on Mortgage Volumes, by Income ...............................................................37

Figures

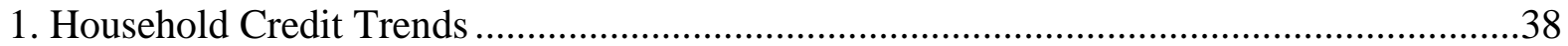

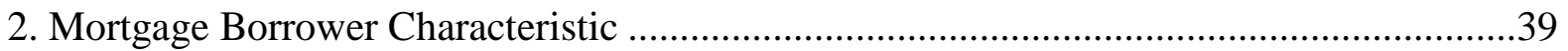

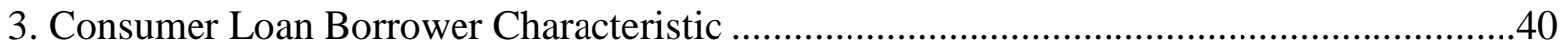

4. Marginal Impact of DSTI on Probability of Default (PD): Mortgages ..............................41

5. Marginal Impact of DSTI on Probability of Default (PD): Consumer Loans .....................42

References 


\section{INTRODUCTION}

A large literature has established the risks to financial stability associated with high household credit growth and leverage (Reinhart and Rogoff (2009), Schularick and Taylor (2012), and Jordà et al. (2016)). In particular, downturns that are accompanied by financial stress are found particularly disruptive since the recoveries that follow them tend to be longer and slower (Claessens et al. (2009) and Abdul et al. (2011)).

As a result, policymakers recognize the importance of ensuring that rapid growth in household credit does not lead to a build-up of vulnerabilities in the form of imprudent household leverage levels. Sectoral macroprudential tools aimed at constraining excessive household borrowing, such as constraints on loan-to-value (LTV) ratios or debt-service-toincome (DSTI) ratios, have proven effective in containing excessive credit growth (Claessens et al. (2013), Kuttner and Shim (2016), Akinci and Olmstead-Rumsey (2015), Alam et al. (2019), and that they are more effective at slowing down credit than other macroprudential tools, such as higher capital buffers for banks.

These borrower-based macroprudential tools are also increasingly recognized as bolstering borrowers' resilience to shocks. They cap the maximum borrowing to sustainable levels, thereby lowering the likelihood of default. And they can also reduce the macroeconomic impact of widespread defaults or crises when they occur. Mian and Sufi (2009) use countylevel data in the U.S. to show that the impact of the Great Recession, as measured by unemployment and drop in consumption, was relatively higher in counties where household leverage grew faster prior to the crisis. Tools that can contain the build-up of borrower leverage can therefore be expected to increase resilience to aggregate shocks, with loan-tovalue constraints providing resilience against shocks to asset prices, and debt-service constraints providing resilience to shocks to income and interest rates (IMF 2014).

In recognition of these benefits, macroprudential tools, particularly those addressed at borrowers, are becoming more widely used in various jurisdictions: in Europe, Cyprus, Hungary, Portugal, Slovenia, Estonia, Lithuania, Poland and Slovakia have such limits in place (Committee on the Global Financial System (2016), ${ }^{2}$ European Systemic Risk Board (2018)), and DSTI limits have been in use for much longer in a number of other countries outside Europe (e.g., Korea and Singapore).

Despite the increasing prevalence of DSTI limits, the existing theoretical or empirical literature provides scant guidance on the appropriate calibration of such a limit; that is, where should the limit be set so as to achieve the policy maker's objective of increasing borrowers'

\footnotetext{
${ }^{2}$ While there are no legally binding hard limits in the Czech Republic, the Czech National Bank (CNB) makes non-binding recommendations to banks regarding LTV and DSTI limits.
} 
resilience to shocks, without unduly limiting households' access to credit? This paper develops empirical analysis that can help in answering that question. This analysis was conducted in the context of Romania, where the central bank was minded to introduce such a DSTI limit, in light of past experience against the backdrop of strong credit developments in the household sector (see further in section 2), to complement an existing limit on the LTV.

This analysis takes advantage of loan-level data that are available in Romania from a comprehensive household credit register with detailed information on all loans extended by the banking sector to individuals. This register provides details of borrower characteristics, as well as the default incidence on individual loans. We enrich this dataset to also include income data for borrowers using information from tax returns, in order to construct a DSTI ratio for each borrower. Using this detailed information on more than 200,000 mortgages and 460,000 consumer loans, we study how the probability of default of a loan depends on the total indebtedness of the borrower, while also controlling for other bank-, borrower-, and loan-level characteristics.

A first and novel finding of this analysis is that the relationship between probability of default and the borrower's DSTI ratio is non-linear. For mortgage borrowers, the probability of default increases with a marginal increase in the DSTI ratio only from a certain threshold, which we measure at 50 percent based on Romanian data. Below this threshold, there is no measurable increase in the probability of default associated with an increase in DSTI. This finding is important from a policy perspective, since it argues for setting a regulatory limit below the threshold identified here empirically, so as to ensure that the borrowers remain below the threshold even in the presence of shocks.

A second novel finding is that for borrowers who only carry consumer loans, the threshold above which increases in DSTI lead to increases in probability of default is lowerand measured about 30 percent based on Romanian data. A lower threshold is consistent with the idea that the perceived penalty for borrowers from defaulting on consumer loans is lower than that from defaulting on a mortgage, which would typically result in the borrower losing her home. ${ }^{3}$

The analysis also yields a number of other findings that can be taken into account in the calibration of a limit on DSTI. First, we find that loans denominated in foreign currency are associated with a higher probability of default. And second, we confirm a finding first reported by Kelly et al. (2015) for Irish data, that first time buyers are less likely to default, compared to other borrowers.

\footnotetext{
${ }^{3}$ D'Alessio and Iezzi (2013) note that the DSTI limit for unsecured loans should be lower than for the secured. Their conclusion is based on the fact that secured loans are less risky due to the collateral (lender perspective). In this paper, we are able to document - using borrower-level data - that debtors default at lower DSTI ratios on an unsecured loan compared to a secured one (borrower perspective).
} 
The loan-level data also allows us to perform counterfactual analysis. Since we observe the distribution of actual DSTI ratios, and know how probability of default varies with DSTI, we can compare default rates with and without a limit being in place. In this exercise, we apply the threshold chosen by the National Bank of Romania (NBR), which is 40 percent. Our counterfactual analysis indicates that had the limit been in place for all the loans in our sample, the probability of default would have been lower by 23 percent. We also show that the largest reduction in default probabilities occurs for low-income borrowers, thereby achieving its objective of safeguarding the financial health of these borrowers.

Our analysis demonstrates the importance of using microdata for policy analysis. Yet, the use of such loan-level data is still nascent in the literature, which instead typically examines macroprudential policy using aggregate or bank-level data. Lack of access to microdata has led some researchers to rely on survey data. For instance, Fuster and Zafar (2014) design a survey to measure the impact of changes in macroprudential and monetary policy on households' willingness to pay. They find that a relaxation of down-payment constraints, or an exogenous increase in non-housing wealth, has large effects on willingness to pay, especially for relatively poorer and more credit-constrained borrowers. Igan and Kang (2011) use survey data in Korea and find that lower expectation of house prices after policy intervention leads to postponement of plans to buy property, particularly by the households who already own one, but not by those who do not own a property. Gross and Población (2017) use Household Finance and Consumption Survey (HCFS) from seven countries to compare the effectiveness of implementing a DSTI cap versus a cap on LTV and find that a cap on DSTI is more effective in reducing probability of default for households than a cap on LTV. Using a counterfactual limit on DSTI at 50 percent, they find that the exposureweighted probability of default falls by 30 to 50 percent, depending on the country. Bals et al. (2015), McCarthy (2014) and May and Tudela (2005) all find that DSTI is an important predictor of probability of default using survey data in Hungary, Ireland and United Kingdom, respectively.

The main drawback of such studies is the lack of true (observed) default data, and thus conclusions are based on model generated default rates or survey-based (willingness to pay) information. Where actual micro-data has been used, the focus has mostly been on evaluating the impact of macroprudential policies on credit growth and house prices. Jimenez et al. (2017) study the impact of dynamic provisioning, a policy used in Spain between 2000 and 2016, on smoothing the credit cycle. Gambacorta and Pabn (2017) conduct a meta-analysis in conjunction with a number of central banks using credit register data and find that macroprudential policies have been effective in stabilizing credit cycles. Kukk (2016) uses credit register data in Estonia to confirm that lower income and higher debt service ratios are associated with a higher probability of arrears. 
To our knowledge, our work is the first attempt to use credit register data to guide the calibration of a macroprudential tool. The closest attempt is that by Kelly et al. (2015), mentioned above, who rely on loan-level data to study the behavior of first-time buyers compared to other home buyers. They find that first-time buyers have lower default rates having controlled for borrower and loan characteristics, suggesting that the regulatory treatment of first-time buyers should be differentiated relative to other mortgages.

Finally, it is important to highlight at the outset the scope of our analysis. While we do consider the impact of the proposed regulation on credit provision, a full welfare analysis, including the impact of DSTI limits on financial inclusion, and steady state financial intermediation is outside the scope of the paper. We also do not attempt to consider second round effects, such as on the macroeconomy or loan pricing. Nevertheless, the analysis highlights the importance of DSTI limits for borrower resilience; an element that should enter any broader welfare analysis.

The remainder of the paper is organized as follows: Section 2 provides an overview of the experience in Romania. Section 3 describes our data and the characteristics of the borrowers in our sample. Section 4 presents our economic analysis. In section 5, we discuss the amendments to the existing NBR regulation No. 17/2012 and its relation to our econometric analysis. Section 6 assesses the impact of the new regulation on probability of default and credit volumes. Section 7 concludes.

\section{THE EXPERIENCE OF ROMANIA}

Eight years after the height of the crisis, Romania is once again facing a pick-up in household credit. After a period of contraction followed by lackluster growth in the aftermath of the financial crisis, household credit growth picked up starting in 2015. The flow of new mortgage credit reached a historical high, while the flow of new unsecured consumer lending reached levels seen prior to the crisis (see Figure (1)).

Romania has a long history of using macroprudential tools, having implemented caps on DSTI and LTV as early as 2003. Using the same credit register data as employed in this paper, Epure et al. (2017) document that these tools have been effective in impacting credit growth. Namely, they show that tighter macroprudential conditions are associated with a significant decline in household credit, and particularly so for ex-ante riskier borrowers. In addition, Neagu et al. (2015) show that such policies are indeed needed: using bank-level data, they find that bank self-regulation leads to higher NPL rates as banks behave in a pro-cyclical manner by easing credit standards during economic expansions.

An existing regulation in Romania addressed over-indebtedness of households and 
constrained the maximum DSTI on consumer loans through a requirement for banks' own risk management. ${ }^{4}$ The analysis in this paper was conducted to guide a re-design of the existing macroprudential constraint, which the NBR put in place in October 2018. ${ }^{5}$ The amendments improve on the original regulation in terms of transparency and effectiveness, by introducing a simple numerical limit, and expanding the scope to cover all household loans, including mortgages. Furthermore, the new regulation will apply to banks and nonbanks (non-banks were hitherto not subject to any restrictions on DSTI).

The new regulation limits the maximum DSTI for all new household loans (mortgage or consumer) at origination to 40 percent, where DSTI is defined as the ratio of household's total indebtedness to net (of taxes) income. In other words, the amount of a new loan to a household is limited to a level such that all debt service (associated with the new loan as well as existing loans) is no higher than 40 percent of the borrower(s)' income. ${ }^{6}$ For FX denominated loans this limit is lower, at 20 percent. Two exceptions are envisaged: for borrowers acquiring their first home (borrower-occupied dwellings), including loans under the Prima Casa program 7 , the new regulation raises this ceiling to 45 percent. Second, the regulation allows for an exemption from the application of the DSTI limit for up to 15 percent of a lender's flow of new credit to households. The regulation became effective on January 1, 2019 (see a more detailed discussion of the amendments in section (2)).

This paper shows that a borrower's probability of default is highly sensitive to small increases in the DSTI ratio when this indicator reaches the 50 percent level. In light of this, the NBR's regulation implements a limit on indebtedness at 40 percent in order to ensure that a borrower's DSTI remains below the critical level even after shocks to interest rate, income and exchange rate are taken into account. We discuss the capacity of a loan originated at a DSTI of 40 percent to withstand such shocks before reaching the critical threshold of 50 percent, in Section V.A.

\footnotetext{
4 The NBR Regulation No. 17/2012 stipulated that all consumer loans granted have to be consistent with the maximum level of DSTI ratio established in the bank's internal regulations after considering an interest rate shock, an FX shock and an income shock of specified sizes. The regulation required consumer loan borrowers to be able to withstand: (i) a 35.5 percent depreciation if denominated in EUR, 40.9 percent if in U.S. dollars and 52.6 percent for loans in other FX; (ii) a 0.6 percentage point increase in interest rate; and (iii) a 6 percent reduction in income.

${ }^{5}$ Amended NBR regulation number 17/2012: http://www.bnr.ro/page.aspx?prid=15396

${ }^{6}$ A limit on total DSTI have also been recently introduced in Singapore and Korea.

${ }^{7}$ Prima Casa is a nationwide scheme designed to support first-time home buyers. Loans granted under the program to eligible borrowers benefit from a partial government guarantee, and are, as a result, subject to a ceiling on the interest margin charged to the borrowers.
} 


\section{DATA}

The work in this paper relies on borrower- and loan-level data, gathered from two main sources: most of the data is based on the information in the Central Credit Register, covering all consumer or mortgage loans above RON 20,000 on balance sheet of banks as of June 2016. The same loans are observed in June 2017 to register their performance status 1-year ahead (performing vs. non-performing). The Central Credit Register offers a wide variety of information regarding the type of loan and some borrower characteristics. This information includes loan type (consumer secured or unsecured, regular mortgage or a mortgage under the Prima Casa program), currency denomination, residual maturity, identifier of the originating bank, and borrower's age and county of residence. For loans with an original principal of less than RON 20,000, we use data from the Credit Bureau. The use of both registers gives us a more complete picture of total indebtedness of individuals in our analysis.

The interest rate, used for the computation of debt service, is extracted from the Monetary Balance Sheet. This is the average interest rate reported by each bank for various classes of loans, differentiated by loan category, maturity and currency. The monthly loan installment is computed using a constant annuity assumption, taking into account a loan's residual maturity and the interest rate.

Data on monthly income provided by the Ministry of Public Finance is then used to compute the DSTI ratio. The latest available data on income are wages reported for the fiscal year of 2016. The information from the two data sources is consolidated by borrower using the national personal identification number.

DSTI ratio for each borrower is calculated as the monthly loan installment, as follows:

$$
\text { DSTI }=\frac{r}{\left(1-(1+r)^{-n}\right)} \frac{S}{V}=f_{d} \frac{S}{V}
$$

where $n$ is the remaining loan term, expressed in months, $r$ is the current monthly interest rate, $S$ is the remaining principal on the loan, and $V$ is the monthly income. The first term on the right-hand-side is referred to as the annuity factor. The concept corresponds to the current DSTI (as opposed to DSTI at origination), as it takes into account remaining principal and maturity, and current interest rates.

Mortgage loans in Romania are almost exclusively variable rate loans. There are also no nonstandard loans (such as interest-only loans). These characteristics imply that the variables in equation (1) could be considered as a relatively complete set of information describing the mortgage loans. 
The monthly loan installment is the sum of debt-service for all loans undertaken by a borrower. In other words, the DSTI ratio for each borrower measures his or her overall indebtedness level. In the notation of equation (1), for a borrower with $k$ loans, DSTI is calculated as:

$$
\left(\sum_{i=1}^{k} \frac{r_{i} S_{i}}{\left(1-\left(1+r_{i}\right)^{\left.-n_{i}\right)}\right.}\right) * \frac{1}{V}
$$

For borrowers with DSTI values above 300 percent and below 5 percent, the DSTI ratio is winsorized at those respective values. In addition, borrowers with a salary below the minimum wage are eliminated from the sample.

The initial selection covers about 356 thousand mortgage loans and over 2 million unsecured consumer loans, outstanding as of June 2016. In order to exclude house purchases for speculative reasons, we only consider borrowers with at most one mortgage loan. In addition, we exclude all loans that are: (i) restructured or refinanced; (ii) converted from FX to RON; (iii) flagged "unlikely to pay" under the EBA definition of nonperformance; (iv) with overdue payments more than 90 days, or (v) with residual maturity less than 12 months (as these loans drop off the database before June 2017). The final step in constructing the database consists of identifying the loans that are still on banks' balance sheets in June 2017. Those loans that have become non-performing (registering more than 90 days past due) are flagged.

Relative to the initial sample of all loans in the database as of June 2016 (356,321 mortgages and 2,012,294 consumer loans), our final sample has a coverage of 56 percent and 23 percent of the total loans in the mortgage and consumer database, respectively, after the exclusions discussed above are applied (Table 1). The main contributor to the drop in coverage of mortgage loans is lack of information on debtors' income (23 percent). In the case of consumer loans, the low (residual) maturity implies that many loans are settled earlier than in one year and thus drop out of the sample, when the status of the loan is re-examined in June 2017 (43 percent). Exclusion of borrowers with more than one mortgage accounts for only 4 percent of total mortgages. In Section IV, we show that our main results are robust to including borrowers with more than one mortgage in our sample.

After merging the two datasets (the June 2016 and June 2017 observations), we are left with 200,598 borrowers with a mortgage loan and 467,969 borrowers who only have unsecured consumer loans. We run our econometric model separately for these two subsamples: all borrowers with a mortgage loan are treated in the mortgage subsample and their default behavior is analyzed using the mortgage model. Out of the 200,598 borrowers with a mortgage loan, 59,482 (29.6 percent) also have at least one consumer loan. 
The consumer subsample (those borrowers with only consumer loans) contains 467,969 borrowers, out of which 411,000 (88 percent) have only one loan, 51,400 (11 percent) have two loans and 5,600 (1 percent) have 3 or more consumer loans. There are no overlaps between the two subsamples.

Our regression analysis is conducted at borrower level, rather than at loan level. In other words, each borrower appears in our sample only once. Given that we exclude borrowers with more than one mortgage, for the mortgage subsample there is a one-to-one mapping between borrowers and loans. In the consumer subsample, each data point refers to a borrower, some of whom may have more than one loan. In both subsamples, loan characteristics such as interest rate and residual maturity are calculated using an exposureweighted average. In determining default status in the mortgage subsample, we only consider the default of the mortgage loan (regardless of the status of any consumer loans the borrower may have). In the consumer loan subsample, if a borrower has multiple consumer loans, they are considered in default if any of the loans become non-performing.

One drawback of our data sample is the lack of information regarding co-borrowers. Specifically, all loans are identified by the primary borrower. Furthermore, the data on monthly income from the Ministry of Public Finance does not allow for identifying households and thereby pooling their income. This gap in our information might partly explain the large share of borrowers with very high DSTI (see section 3.1), as only the income of the main borrower is accounted for in the calculation of DSTI, while banks determine the borrowing capacity based on the combined income of all co-borrowers. In order to mitigate the potential effects of over-estimating the debtors DSTI we run a regression on the sample of debtors with DSTI below 100 percent (Table 4, column 2) and find that our main findings remain valid.

\section{A. Borrower Characteristics}

The borrower characteristics are described in Table (2) and Figures (2) and (3). Mortgage loans in our sample are roughly equally split between domestic currency and foreign currency (FX) denominated loans. The FX denominated loans, are almost entirely denominated in euros, although some 3000 CHF-denominated loans remain. The borrowers are roughly equally split between low-income earners (defined as those with income below the economy-wide average), average-earners (with income between the average and up to twice the average level) and high-earners (income above twice the average). Roughly 60 percent of the loans are issued under the Prima Casa program. By far the majority of loans in our sample were originated after 2010 (85 percent). The loans originated before 2009 show a significantly higher probability of default compared to the newer vintages (unconditional on other loan characteristics). Almost 70 percent of mortgage borrowers are below 40 years of age and more than 90 percent are below 50 years of age. Older borrowers 
also demonstrate a higher probability of default on average. Two thirds of mortgage loans have a DSTI below 40 percent, while an additional 10 percent have a DSTI between 40 percent and 50 percent. The average DSTI level for low-income borrowers (48 percent) is more than double compared to that of high-income borrowers (19 percent). Looking at unconditional relationships, the probability of default rises rapidly for DSTI levels above 50 percent and drops modestly with income level.

The median consumer loan is significantly smaller than a mortgage (median 21,000 lei compared to 158,000 lei for mortgages) and shorter in residual maturity (median 3 years compared to 24 years for the mortgages). Consumer loans have a maximum maturity of five years at origination, which is why loans issued in the last two years of the sample (2015 and 2016) represent almost 80 percent of our consumer loan observations. Unlike mortgages however, the distribution is much more skewed towards low income borrowers, with 56 percent of consumer loan borrowers belonging to the below average income group. This feature is often associated with the need to take on debt for consumption, in order to complement income Voinea et al. (2018). Furthermore, the asymmetry between DSTI levels by income groups is not as pronounced (23 percent for low-income borrowers versus 19 percent for high-income borrowers).

The probability of default for consumer loans is significantly higher than that of mortgages (1.5 percent vs. 0.1 percent, in our sample). Probability of default is highly correlated with income strata, dropping sharply for income levels above the $40^{\text {th }}$ percentile. Similar to the mortgages, there is a positive correlation between DSTI and probability of default, particularly for DSTI levels above 30 percent.

Our analysis is based on Point-in-Time (PiT) PDs and aims to explain the factors impacting the cross-sectional differences of PDs and not so much their level throughout time. The aim of the analysis is to show how different borrower characteristics, and specifically DSTI, impacts PDs rather than to explain the evolution of PDs through time. Therefore, to the extent that the relationship between borrower characteristics and PD remains constant, the choice of the year for which we have cross-sectional data should not be relevant. We note however, that 2016-2017 was a period of relative tranquility, implying relatively low average PDs.

\section{ECONOMETRIC MODEL AND RESUlts}

Our empirical specifications examine the impact of DSTI on default probability controlling for differences in loan and borrower characteristics, separately for mortgage borrowers and borrowers who only have consumer loans. 


\section{A. Mortgages}

The aim of the mortgage model is to establish the conditional relationship between DSTI level and the one-year ahead probability of default (as of June 2017), controlling for all other borrower characteristics, as observed in June 2016. In order to capture the potentially nonlinear impact of increases in DSTI on probability of default, we define five distinct ranges of DSTI and evaluate the impact of a marginal increase of DSTI on probability of default in each of these ranges separately. Specifically, we assume the following model for the probability of default:

$$
y_{i}=\alpha+\sum_{j=1}^{5} \beta^{j} d_{i}^{j} D S T I_{i}+\sum_{k} \delta^{k} X_{i}^{k}+\epsilon_{i}
$$

where $y_{i}=\log \left(\frac{P D_{i}}{1-P D_{i}}\right)$ is the logit transformation of the probability of default for loan $i$, DSTI $_{\mathrm{i}}$ is the debt burden associated with debtor $i$, and $d_{i}^{j}$ is a dummy variable which is 1 if loan $i$ belongs to range $j$ and zero otherwise. $X_{i}^{k}$ are other characteristics of loan $i$. Note that if $\beta^{j}$ s are not significantly different from each other, the impact of DSTI on $y_{i}$ is linear, whereas our specification allows for piece-wise linear functional form, with a larger $\beta^{j}$ indicating a higher marginal impact of DSTI on $y_{i}$ in that range. To implement equation (2) above, we define 5 ranges for DSTI as described in Table (3).

The regression results of our mortgage model are shown in Table (4). Each column indicates a different specification. Starting with the most basic specification in column (1), we evaluate the impact of DSTI on the probability of default, controlling for the residual maturity of the loan, the currency of the loan (EUR, CHF or RON), whether the mortgage is part of the Prima Casa program and whether the borrower also has a consumer loan.

Starting with non-DSTI characteristics of the borrowers, all explanatory variables have significant coefficients with correct signs. Specifically, foreign currency loans are much more likely to default, with this impact stronger for CHF loans. While only 1.5 percent of the loans (2,956 loans) are denominated in CHF, the coefficient is highly significant. Prima Casa loans have a lower probability of default, ceteris paribus. This is consistent with the existing evidence Kelly et al. (2015) showing that first-time buyers have a lower probability of default. Having a mortgage and a consumer loan makes a borrower more likely to default, controlling for the total debt-burden level. Finally, the longer the residual maturity, the higher the probability of default. Recall that the unconditional correlations shown in section (3.1) indicated a higher probability of default for loans originated earlier in our sample. Our econometric analysis shows that, ceteris paribus, these loans should have a lower probability of default, given their shorter residual maturity. Putting together these two pieces of evidence, one concludes that loans originated prior to crisis were perhaps subject to lower underwriting standards. This is consistent with findings from several studies (Acharya et al. (2009), Maddaloni and Peydro (2011)). 
Turning to the impact of DSTI on probability of default, we note that for DSTI levels below 50 percent, there is no significant relationship between an increase in DSTI and the probability of default (coefficients of DSTI interacted with dummies for range $=1$ and range=2). However, for DSTI larger than 50 percent, the marginal effect of DSTI on probability of default becomes positive and significant.

This result is robust to other specifications. As discussed earlier, our database does not include information on co-borrowers. As a robustness check, in column (2) we eliminate all loans with a DSTI greater than 100 percent, on the basis that these loans must be supported by more than one income since no single borrower can pay a loan with a debt service burden greater than disposable income ${ }^{8}$. In column (3), we add LTV as an explanatory variable. The coefficient on LTV is positive and significant, indicating a higher probability of default for high LTV borrowers, as expected. In column (4) we add the (log) size of the loan as an explanatory variable. The coefficient of size is negative and significant, indicating that borrowers with larger loans are less likely to default. Note that the debt burden contains information regarding the debt size, nevertheless, it may not be a sufficient statistic. For instance, given the same DSTI a larger loan size implies a higher wage or more favorable loan terms (lower interest rate or a longer original term). Our results, therefore, indicate that richer borrowers, or those with a more favorable loan contract are less likely to default. Specification (5) adds a dummy variable for high-income earners, defined as those with a wage income at least twice the economy-wide average, and a dummy variable for lowincome earners, defined as those with a wage income below the average level. Given that we already control for the DSTI level and loan size, income level indicators are not statistically significant in explaining the probability of default.

In specification (6) we add log income as opposed to dummies for income groups. We still find that income is not a statistically significant explanatory variable, indicating high multicollinearity between income, loan size and DSTI. Our final and preferred specification, in column (7) includes the loan size as an explanatory variable, but not income. In addition, we include dummies for the residence of the borrower, the lending bank and the year of loan origination (coefficients not reported).

Table (5) presents the marginal impact of a change in DSTI on the percentage change in probability of default, for each of the DSTI ranges. In other words, the coefficients demonstrate $\frac{(d P D / d D S T I)}{P D}$. For instance, the marginal impact of DSTI in range 3, in column (7)

\footnotetext{
8 There are other reasons for observing an inflated DSTI ratio compared to the actual DSTI. For instance, if income is under reported the calculated DSTI would be larger than in reality.
} 
—our preferred specification—is 1.6. This means that a 10-percentage point increase in DSTI increases probability of default by 16 percent.

Figure (4) presents these marginal impacts graphically. The figure shows the percentage increase in probability of default in each range for a 10-percentage point increase in DSTI. The confidence intervals are shown about the point estimates. As discussed above, the figure shows that the marginal impact is not statistically significant for DSTI levels below 50 percent. On the other hand, a 10-percentage point increase in DSTI leads to an increase in probability of default of 16 percent for DSTI levels between 50 to 90 percent, an increase in probability of default of 14 percent for DSTI between 90 and 120 and an increase in probability of default of 8 percent for DSTI above 120 percent.

As a robustness analysis, we also test a linear version of equation (2), i.e. where $\beta^{j}$ s are equal. The results are demonstrated in Table (6). In all specifications (defined similarly to our main results), DSTI is positively and significantly correlated with a higher probability of default.

The mortgage regressions are repeated in an alternative sample where debtors with more than one mortgage loans are included. These account for 4 percent of the original sample or 14.8 thousand loans. The results are reported in Tables (7) and (8). We exclude the variable LTV as the variable is not well defined for two loans. We include a dummy variable for debtors with more than one loan. The dummy variable is not statistically significant and our main result remains robust: for DSTI levels below 50 percent, there is no significant relationship between an increase in DSTI and the probability of default, whereas for DSTI larger than 50 percent, the marginal effect of DSTI on probability of default becomes positive and significant.

\section{B. Consumer Loans}

For consumer loans we employ a similar estimation strategy to that of the mortgage subsample in order to estimate the marginal impact of DSTI on probability of default. We use different ranges for the DSTI, reflecting the distribution of loans along the DSTI axis. Specifically, we use the ranges in Table (9) for the consumer loan model. Consistent with the observation of higher probability of default and lower median DSTI for consumer loans compared to mortgages, the range thresholds of DSTI for consumer loans are smaller and more granular towards the lower end of the DSTI range.

The regression results of our consumer loan model are shown in Table (10). Column (1) shows our baseline specification, where probability of default is regressed on DSTI allowing for different coefficients in each of the five ranges specified in Table (9). Similar to the mortgage model, the elasticity of probability of default to DSTI is not significant for ranges 
below a certain threshold, namely 30 percent. Whereas for values above 30 percent, indebtedness has a positive and significant impact on probability of default. Consistent with our mortgage results, longer residual maturity increases the probability of default.

In columns (2)-(7) we test the same relationship but with alternative specifications. Column (2) adds the borrower's age as an explanatory variable, which is negative and significant: older borrowers are less likely to default. In the specification of column (3) we eliminate all borrowers with a DSTI $>100$ percent. The results now show a significant and positive impact of DSTI for all DSTI levels. The results are somewhat affected by the fact that the default ratio is significantly higher for loans with DSTI greater than 100 percent (2.6 percent compared to 1.5 percent for loans with DSTI less than 100 percent). For this reason, we use the full subsample for the subsequent specifications. Column (4) adds the size of the loan, which, similarly to the mortgage model, has a negative and significant impact on default probability, likely indicating that borrowers with larger loans have higher incomes. Unlike the mortgage model, DSTI and loan size are not sufficient statistics and adding dummy variables for income group of the borrower still adds discriminatory power to the regression (column (5)): borrowers who earn a wage below the economy-wide average (more than twice the economy-wide average) are more (less) likely to default, even controlling for the size of loan and the level of indebtedness. In column (6), we replace the income group indicators with log of income as an explanatory variable, which is negative and significant. Finally, in column (7) we add bank, region and origination year dummies (coefficients not reported). This is our preferred specification. Our main result remains robust across specifications: For consumer loans, DSTI has a positive and significant impact on probability of default, at levels above 30 percent.

Table (11) presents the results described above in terms of marginal effects of DSTI on the probability of default, which are easier to interpret. The highlighted figures show the percentage increase in probability of default for a 1 percentage point increase in DSTI. For instance, the coefficient of range 3 in column (7) indicates that a 1 percentage point increase in DSTI increases the probability of default by 0.8 percent. The results are shown graphically in Figure (5). For ease of interpretation, the figure shows the percentage change in probability of default for a 10-percentage point increase in DSTI, in each DSTI range. Increases in DSTI lead to increases in probability of default for DSTI levels above 30 percent. A 10-percentage point increase in DSTI level leads to a 8 percent increase in probability of default for the 30-50 DSTI range, a 6 percent increase in probability of default for the 50-70 DSTI range, and a 3 percent increase in probability of default for the DSTI above 70 percent range.

The fact that consumer loans are sensitive to increases in DSTI at a lower level of DSTI is consistent with the observation that they are generally riskier loans compared to mortgages, 
as indicated by a significantly higher unconditional probability of default. As of June 2018, the NPL ratio of consumer loans was 5.2 percent, compared to 3.0 for mortgages. ${ }^{9}$

While intuitive in this context, to our knowledge our study is the first to document higher sensitivity of consumer default rates to DSTI compared to mortgages. One explanation for this result lies in the different consequences of default on a consumer vs. mortgage loan. In particular, the full recourse status of mortgages in Romania provides a strong disincentive for mortgage defaults ${ }^{10}$. Moreover, in the case of mortgage defaults, the lender can foreclose on a property which is, often, the borrower's primary residence, while the consequences of a default on (unsecured) consumer loans are far less severe. As a result of these higher costs of default the mortgage borrower may tolerate a debt-burden of up to 50 percent before he defaults, while a borrower with consumer loans only may decide to default at a point where the debt-service burden is much more moderate.

\section{NEW NBR REGULATIONS ON DSTI LIMITS}

In October 2018, the NBR Board adopted a regulation amending and supplementing NBR Regulation No. 17/2012, which we referred to in section (2). According to the new provisions, the ceiling for household loan indebtedness is set at 40 percent of the net income for leu-denominated loans and 20 percent for foreign currency loans. The total level of indebtedness is measured as the ratio of monthly debt service to the monthly net income. For first-time buyers who intend to use the property as their primary residence, including loans granted under the Prima Casa program, the maximum level of indebtedness is set at 45 percent. The regulation applies to banks and NBFIs alike.

The amendments simplify the existing regulation in many dimensions and level the playing field between bank and non-bank lenders, a factor that is important for consumer loans since more than 20 percent (as of June 2018) of consumer loans are granted by nonbank financial institutions that hitherto, were not included in the perimeter of the maximum indebtedness regulation.

The new regulation also simplifies the methodology for calculation of maximum loan level permitted. Unlike the old methodology, no adjustments are made to the income for subsistence. The limit applies to the DSTI at origination, without any adjustments for stress.

\footnotetext{
${ }^{9}$ In our sample the disparity is even sharper: the observed default rate for consumer loans is 1.5 percent whereas for mortgages it is 0.1 percent.

${ }^{10}$ While the Datio in Solutium law is in place, the Constitutional Court has mandated that it can only be applied to cases where default was due to unexpected circumstances. As a result, there has only been few cases where the law was applied.
} 
In other words, the 40 percent limit is set such that there is built-in room for reasonable shocks to interest rate or exchange rate during the life of the loan.

Furthermore, prior to the adoption of the new regulation the maximum level of indebtedness was not explicit. Instead, banks had to ensure that the indebtedness level was consistent with their internal risk management limits, leading to variable levels of indebtedness accepted for the same borrower at different lending institutions. The new regulation ensures transparency and a level playing field among the lenders.

In addition, the regulation allows for an exemption from the application of the DSTI limit for up to 15 percent of a lender's flow of new credit to households. The application of such exemptions has become common and is in line with the approach taken in other jurisdictions, namely New Zealand, the U.K., and more recently Portugal. The aim is to reduce efficiency costs associated with imposing a limit on loan size. For instance, the exemption allows lending to take place in cases where a bank believes there are good reasons to lend to a borrower despite a high DSTI ratio (good collateral, good prospects for income, temporary reduction in income, etc.).

The slightly higher cap for first-time buyers, including those through the Prima Casa program, is supported by our analysis outlined in section (4). As discussed above, Prima Casa borrowers have a lower probability of default and therefore can support a higher DSTI compared to other mortgages, ceteris paribus, which is the basis for this caveat in the adopted regulation.

\section{A. Resilience to Shocks}

The analysis in the previous section shows that mortgage loans become sensitive to increases in DSTI ratios at DSTI ratios close to 50 percent. The ceiling of DSTI at origination in the regulation was set at a lower level, namely 40 percent, in order to build in some resilience to shocks. In the absence of any changes to the original income or interest rate of the loan, DSTI of a loan should remain constant throughout the life of the loan. But changes to DSTI are possible if there are income shocks, or changes to the interest rate, or, in the case of FX denominated loans, changes to the exchange rate.

To demonstrate the built-in buffer associated with the proposed calibration of the DSTI limit, in this section we analyze the capacity of a borrower whose loan was originated at a DSTI ratio of 40 percent to absorb such shocks before reaching the critical 50 percent level indicated by our analysis. Referring to equation (1) we note that the DSTI of a loan is calculated as:

$$
\text { DSTI }=\frac{r}{\left(1-(1+r)^{-n}\right)} \frac{S}{V}=f_{d} \frac{S}{V}
$$


If there are shocks to any of these variables (income, interest rate and exchange rate), the new shocked DSTI can be calculated as follows:

$$
\operatorname{DSTI}_{\text {shocked }}=f_{d}^{\text {shocked }} \frac{1+\text { shock }_{F X}}{\left(1-\text { shock }_{\text {income }}\right)} \frac{S}{V}
$$

where $f_{d}^{\text {shocked }}$ is the annuity factor modified to incorporate the interest rate shock:

$$
f_{d}^{\text {shocked }}=\frac{r+\text { shock }_{I R}}{\left(1-\left(1+r+\text { shock }_{I R}\right)^{-n}\right)}
$$

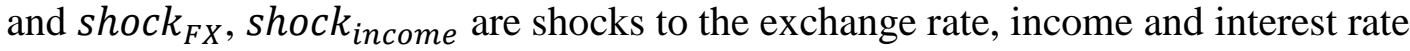
respectively. Note that $n$ remains the original time to maturity and $S$ and $V$ the original principal of the loan and income, respectively.

To evaluate the capacity of a borrower with a DSTI of 40 percent to absorb shocks, we consider a mortgage loan with maturity of 30 years and original interest rate of 4 percent, which is close to the median observed in our sample. We then calculate the shocks that would lead such a borrower to a DSTI of 50 percent.

We consider 5 scenarios, which are described in Table (12). Scenarios 1 to 3 are applied to a leu-denominated loan and scenarios 4 and 5 are applicable to a FX denominated loan. As demonstrated in scenario (1), the loan described above can absorb interest rate increases of up to 200 basis points before it reaches a 50 percent DSTI level. Alternatively, the borrower could absorb a 20 percent reduction of income before the DSTI reaches the critical 50 percent level (scenario (2)). Finally, a 150 bps increase in interest rate and a 5 percent drop in income could take the indebtedness level to the critical threshold (scenario (3)).

In scenarios (4) and (5), we consider an FX loan with the same characteristics as the loan above, except the original DSTI level which is 20 percent as prescribed by the regulation. We then calculate an equivalent DSTI threshold for FX loans, which would make it as likely to default as the leu-denominated mortgage at a DSTI of 50 percent. Specifically, we consider the leu-denominated mortgage described above (maturity 30 years, interest rate of 4 percent, with other characteristics at median in our sample) and compare it with an identical mortgage that only differs in its currency denomination. We then define DSTI Ihreshold such that the probability of default for the two mortgages are the same. This yields a DSTI threshold of 32 percent. Scenarios (4) and (5) show that an FX mortgage loan originated at a DSTI of 20 percent can therefore absorb a 60 percent depreciation (scenario (4)) or a combination of i) 5 percent drop in income of the borrower, ii) a 30 percent depreciation and iii) a 150 bps increase in interest rates (scenario (5)) before reaching the critical 32 percent DSTI threshold. 


\section{Counterfactual Analysis}

In this section, we provide a simple counterfactual analysis to quantify the impact of the new regulation on probability of default and credit volumes. To do so, we evaluate how the outcomes in our sample would have changed, had the regulation always been in place. Specifically, we assume that every loan with a DSTI of above 40 percent (20 percent for FX denominated loans) would have been limited to a loan value that brings the DSTI down to 40 (20) percent. We then use this new nominal loan size, combined with other characteristics of the loan to estimate the counterfactual probability of default using our preferred specifications above.

In reporting our results, we correct for the tendency of logistic regression to underestimate the probability of rare events (King and Zeng (2001)). To do so, we calibrate the intercept from equation (2) to match the average probability of default observed in June 2017.

The results are reported in Tables (13) to (16). Table (13) shows the impact of the regulation on probability of default, for various ranges of DSTI. The probability of default for all mortgages drops by 23 percent, with the largest impact on mortgages with highest DSTI (greater than 120 percent). For this category, probability of default drops by roughly 60 percent. The overall impact is similar for leu-denominated and FX loans. The impact for leu-denominated loans in range 1 is zero as this range is defined as loans with DSTI less than 30 percent, and therefore the regulation does not impact loans that fall within this category. We next consider the impact of the regulation on probability of default for borrowers from different income groups (Table (14)). Given the correlation of income and DSTI, the regulation implies the sharpest decline in probability of default for low-income borrowers. For these borrowers, average probability of default drops by close to 40 percent, compared to 6 percent for the high-income group (and 23 percent for the entire sample). In other words, low-income borrowers see the largest benefit in terms of prevention of unsustainable borrowing.

Next, we consider the impact of the regulation on credit volumes. We show the impact on volumes, for different DSTI ranges (Table (15)) and different income groups (Table (16)). The results reflect the impact of the regulation on the probability of default: the sharpest drop in volume is for loans that currently have the highest DSTI, as their nominal values need the largest adjustment. We estimate a 23 percent drop in total loan volumes, with significant difference for leu-denominated vs. FX denominated loans: the impact on leu-denominated loans is smaller at 10 percent, whereas the impact on FX denominated loans is 35 percent. Further, loans with a large DSTI would see the largest adjustment. Both results point to a desirable rebalancing towards domestic currency denominated and low DSTI loans. 
There are a few reasons why the estimated reduction in loan volumes may be exaggerated. First, many high-DSTI loans are in fact contracted with a co-borrower, with a true DSTI ratio that is lower than our measure (which does not consider a co-borrower's income). To the extent that our measure of DSTI is above the actual DSTI, our estimate of the impact that the new regulation would have on loan volumes is also exaggerated.

Furthermore, in the absence of an annual income statement in Romania certain borrowers may not declare their full income to the tax authorities and as such, the DSTI calculated using income tax returns may be overstated, leading to a higher estimate for the reduction in credit than in reality.

In addition, as highlighted in section (4) underwriting standards have improved and many of the newer loans already take the debt-burden of the borrower into account when extending loans. As a result, the regulation will mark a smaller change than implied by our impact analysis, where more than 15 percent of the loans were granted in 2009 or earlier. Finally, our calculation does not take into account the exemption of 15 percent of new flows from the DSTI limit. This provision will contribute to a softer impact on credit volumes.

Turning to consumer loans, we observe that 83 percent of the borrowers with consumer loans already have DSTI lower than 40 percent. Therefore, the regulation does not impact the majority of borrowers with consumer loans granted by banks. This does not necessarily imply that the regulation is not binding or will not be effective in addressing indebtedness for consumer loan borrowers, for a few reasons.

First, our sample does not include loans from non-bank financial institutions, which typically grant loans at much higher rates and shorter maturities. The regulation is binding for loans granted by these institutions and is likely to make a significant impact on that segment of the credit market.

Second, many borrowers with a mortgage and a consumer loan and an overall indebtedness over the prescribed limit may choose to reduce their indebtedness via a reduction in consumer loans. Such a strategic decision would lead to a bigger impact on consumer loan volumes from the regulation, but a lower impact on the volume of mortgage loans. 


\section{CONCLUSION}

In this paper we present empirical evidence to support the calibration of a limit for household indebtedness levels, in the form of a cap on DSTI ratio, by studying the link between actual DSTI and the probability of default.

Our empirical results, based on borrower-level information from the Romanian credit register, show that mortgage PDs become sensitive to increases in DSTI at indebtedness levels about 50 percent. This finding was used in the design of a new regulation in Romania, which limits the DSTI at origination to 40 percent, and thereby builds in some buffer before borrowers reach this critical level and become vulnerable to shocks. For instance, we show that a typical mortgage loan can absorb a 1.5 percent increase in interest rate and a 5 percent reduction in income before it reaches the 50 percent threshold.

The empirical analysis also provides the rationale for further features of the regulatory design. In particular, we document for Romanian data that mortgages denominated in foreign currency are more likely to default, while first-time buyers are less likely to default, consistent with the desirability of a tighter limit on FX loans and a somewhat more generous limit for first-time buyers.

Our results also indicate that in the case of consumer loans, the threshold from which PD becomes sensitive to changes in DSTI occurs at a lower level (from a DSTI of about 30 percent). To the best of our knowledge, the lower threshold for default of consumer loans compared to mortgages has not been documented in the literature. There are intuitive reasons why default threshold for consumer loans may be lower. Defaulting on a consumer loan has less significant consequences compared to defaulting on a mortgage, which often leads to the loss of a borrower's main residence.

Finally, our impact analysis quantifies the resilience benefit of introducing a limit to the DSTI ratio, which we show to lead to a sizable drop in average default probabilities. Default rates would have been lower by 23 percent had all mortgages in our sample complied with the 40 percent (20 percent for FX loans) maximum DSTI rule. The impact is highest for lowincome households who would see a 40 percent reduction in their default rates.

Our results also point to a bigger decline in FX denominated mortgage volumes compared to leu-denominated mortgages, a welcome rebalancing that is due to the tighter limit on DSTI for FX loans. While aggregate mortgage credit volumes could have been lower by 23 percent, we believe that the actual impact may be somewhat lower as we cannot account for co-borrowers in our data set. 
Table 1. Loan Data

\begin{tabular}{|c|c|c|c|c|c|}
\hline & & Mortgage loans & & Consumer loans & \\
\hline 1 & All debtors with a loan in Central Credit Registry - June 2016 & 356,321 & $100 \%$ & $2,012,294$ & $100 \%$ \\
\hline 2 & $\begin{array}{l}\text { Debtors with no arrears, no restructuring, no conversions and } \\
\text { residual maturity above } 12 \text { months - June } 2016\end{array}$ & 321,338 & $90 \%$ & $1,156,372$ & $57 \%$ \\
\hline 3 & Exclude debtors with multiple loans - June 2016 & 306,546 & $86 \%$ & - & - \\
\hline 4 & Debtors still in database - June 2017 & 281,253 & $79 \%$ & 746,937 & $37 \%$ \\
\hline 5 & Debtors with registered income - December 2016 & 200,598 & $56 \%$ & 550,230 & $27 \%$ \\
\hline 6 & Consolidated database - June 2017 (unique debtors) & 200,598 & $56 \%$ & 467,969 & $23 \%$ \\
\hline
\end{tabular}

Source: NBR and IMF staff estimates. 
Table 2. Borrower Characteristics

\begin{tabular}{|c|c|c|c|c|}
\hline & \multicolumn{2}{|c|}{ Mortgages } & \multicolumn{2}{|c|}{ Consumer } \\
\hline & Share & \# borrowers & Share & \# borrowers \\
\hline $\begin{array}{l}\text { Sample size } \\
\text { Currency }\end{array}$ & $100 \%$ & 200,598 & $100 \%$ & 467,969 \\
\hline FX & $51.3 \%$ & 102,872 & $0 \%$ & 0 \\
\hline $\mathrm{CHF}$ & $1.5 \%$ & 2,956 & & \\
\hline EUR & $49.6 \%$ & 99,551 & & \\
\hline Domestic & $48.7 \%$ & 97,726 & $100 \%$ & 467,969 \\
\hline \multicolumn{5}{|l|}{ Other loans } \\
\hline Consumer loan & $29.7 \%$ & 59,482 & \multicolumn{2}{|c|}{$\mathrm{n} / \mathrm{a}$} \\
\hline Mortgage only & $70.3 \%$ & 141,116 & \multicolumn{2}{|c|}{$\mathrm{n} / \mathrm{a}$} \\
\hline \multicolumn{5}{|l|}{ Income } \\
\hline Low wage & $31.8 \%$ & 63,835 & $67.6 \%$ & 316,518 \\
\hline Median wage & $38.6 \%$ & 77,453 & $25.1 \%$ & 117,664 \\
\hline High wage & $29.6 \%$ & 59,310 & $7.2 \%$ & 33,787 \\
\hline Prima Casa & $59.8 \%$ & 119,934 & \multicolumn{2}{|c|}{$\mathrm{n} / \mathrm{a}$} \\
\hline Other loan info & & Median & \multicolumn{2}{|c|}{ Median } \\
\hline $\begin{array}{l}\text { Loan size } \\
\text { (lei) }\end{array}$ & & 147,685 & \multicolumn{2}{|c|}{11,600} \\
\hline $\begin{array}{l}\text { Residual maturity } \\
\text { (months) }\end{array}$ & & 221 & \multicolumn{2}{|c|}{42} \\
\hline $\begin{array}{l}\text { Borrower age } \\
\text { (years) }\end{array}$ & & 36 & \multicolumn{2}{|c|}{46} \\
\hline $\begin{array}{l}\text { Interest rate } \\
\text { (annual percent) }\end{array}$ & & 3.89 & \multicolumn{2}{|c|}{10} \\
\hline $\begin{array}{l}\text { DSTI } \\
\text { (percent) }\end{array}$ & & 31.2 & \multicolumn{2}{|c|}{23.0} \\
\hline
\end{tabular}

Source: NBR and IMF staff estimates.

Note: This table describes the characteristics of the loans and borrowers in our sample. Mortgage refers to the subsample of borrowers with at least one mortgage loan. Consumer refers to the subsample of borrowers with consumer loans only. 
Table 3. DSTI Ranges for Mortgage Loans

\begin{tabular}{llll}
\hline Range $=1$ & {$[0,30)$} & 94,712 & $47.2 \%$ \\
Range $=2$ & {$[30,50)$} & 62,430 & $31.1 \%$ \\
Range $=3$ & {$[50,90)$} & 32,175 & $16.0 \%$ \\
Range $=4$ & {$[90,120)$} & 5,859 & $2.9 \%$ \\
Range $=5$ & $>120$ & 5,422 & $2.7 \%$ \\
\hline Total & & 200,598 & $100.0 \%$ \\
\hline
\end{tabular}

Source: NBR and IMF staff estimates.

Note: We assess the marginal impact of DSTI on mortgage PDs for the ranges defined in this table. The table also indicates the distribution of mortgage loans in our sample across different DSTI ranges. 
Table 4. Mortgage Model

\begin{tabular}{|c|c|c|c|c|c|c|c|}
\hline & (1) & (2) & (3) & (4) & (5) & (6) & (7) \\
\hline Range1\#dti & $\begin{array}{l}0.0236 \\
(0.02)\end{array}$ & $\begin{array}{l}1.316 \\
(0.93)\end{array}$ & $\begin{array}{l}0.0486 \\
(0.04)\end{array}$ & $\begin{array}{l}0.0579 \\
(0.04)\end{array}$ & $\begin{array}{l}-0.160 \\
(-0.12)\end{array}$ & $\begin{array}{l}-0.136 \\
(-0.10)\end{array}$ & $\begin{array}{l}0.161 \\
(0.13)\end{array}$ \\
\hline Range2\#dti & $\begin{array}{l}0.246 \\
(0.34)\end{array}$ & $\begin{array}{l}1.011 \\
(1.25)\end{array}$ & $\begin{array}{l}0.294 \\
(0.41)\end{array}$ & $\begin{array}{l}0.326 \\
(0.45)\end{array}$ & $\begin{array}{l}-0.00114 \\
(-0.00)\end{array}$ & $\begin{array}{l}0.0859 \\
(0.11)\end{array}$ & $\begin{array}{l}0.415 \\
(0.57)\end{array}$ \\
\hline Range3\#dti & $\begin{array}{l}1.439 \star \star \star \\
(3.54)\end{array}$ & $\begin{array}{l}1.878^{\star \star \star} \\
(4.13)\end{array}$ & $\begin{array}{l}1.501^{\star \star \star} \\
(3.68)\end{array}$ & $\begin{array}{l}1.536 * \star \star \\
(3.75)\end{array}$ & $\begin{array}{l}1.254^{\star *} \\
(2.78)\end{array}$ & $\begin{array}{l}1.335^{\star \star} \\
(2.86)\end{array}$ & $\begin{array}{l}1.562^{\star \star \star} \\
(3.80)\end{array}$ \\
\hline Range4\#dti & $\begin{array}{l}1.274^{\star \star \star} \\
(4.11)\end{array}$ & $\begin{array}{l}1.875^{\star \star \star} \\
(4.39)\end{array}$ & $\begin{array}{l}1.344^{\star \star \star} \\
(4.32)\end{array}$ & $\begin{array}{l}1.378^{\star \star \star} \\
(4.42)\end{array}$ & $\begin{array}{l}1.157^{\star \star \star} \\
(3.36)\end{array}$ & $\begin{array}{l}1.218^{\star \star \star} \\
(3.40)\end{array}$ & $\begin{array}{l}1.375^{\star \star \star} \\
(4.39)\end{array}$ \\
\hline Range5\#dti & $\begin{array}{l}0.686^{\star \star \star} \\
(5.20)\end{array}$ & & $\begin{array}{l}0.747^{\star * *} \\
(5.60)\end{array}$ & $\begin{array}{l}0.776^{\star \star \star} \\
(5.79)\end{array}$ & $\begin{array}{l}0.666^{\star \star \star} \\
(4.32)\end{array}$ & $\begin{array}{l}0.696^{\star \star \star} \\
(4.29)\end{array}$ & $\begin{array}{l}0.762^{\star \star \star} \\
(5.58)\end{array}$ \\
\hline residual maturity & $\begin{array}{l}0.0295^{\star \star} \\
(2.61)\end{array}$ & $\begin{array}{l}0.0290^{*} \\
(2.35)\end{array}$ & $\begin{array}{l}0.0341^{\star \star} \\
(3.00)\end{array}$ & $\begin{array}{l}0.0367^{\star *} \\
(3.21)\end{array}$ & $\begin{array}{l}0.0334^{\star *} \\
(2.87)\end{array}$ & $\begin{array}{l}0.0344^{\star *} \\
(2.93)\end{array}$ & $\begin{array}{l}0.0476^{\star \star \star} \\
(3.73)\end{array}$ \\
\hline euro denominated & $\begin{array}{l}0.611^{\star \star \star} \\
(4.62)\end{array}$ & $\begin{array}{l}0.594^{\star \star \star} \\
(4.13)\end{array}$ & $\begin{array}{l}0.612^{\star \star \star} \\
(4.64)\end{array}$ & $\begin{array}{l}0.608^{\star \star \star} \\
(4.62)\end{array}$ & $\begin{array}{l}0.618^{\star \star \star} \\
(4.69)\end{array}$ & $\begin{array}{l}0.614^{\star \star \star} \\
(4.65)\end{array}$ & $\begin{array}{l}0.185 \\
(0.93)\end{array}$ \\
\hline CHF denominated & $\begin{array}{l}1.321^{\star \star \star} \\
(5.48)\end{array}$ & $\begin{array}{l}1.300^{\star \star \star} \\
(4.81)\end{array}$ & $\begin{array}{l}1.237^{\star \star \star} \\
(5.11)\end{array}$ & $\begin{array}{l}1.194^{\star \star \star} \\
(4.93)\end{array}$ & $\begin{array}{l}1.222^{\star \star \star} \\
(5.02)\end{array}$ & $\begin{array}{l}1.213^{\star \star \star} \\
(4.98)\end{array}$ & $\begin{array}{l}1.002^{\star \star} \\
(2.90)\end{array}$ \\
\hline First home dummy & $\begin{array}{l}-1.547^{\star * \star} \\
(-10.15)\end{array}$ & $\begin{array}{l}-1.639 * \star \star \\
(-9.98)\end{array}$ & $\begin{array}{l}-1.583^{\star \star \star} \\
(-10.36)\end{array}$ & $\begin{array}{l}-1.597^{* * *} \\
(-10.44)\end{array}$ & $\begin{array}{l}-1.597^{\star \star \star} \\
(-10.44)\end{array}$ & $\begin{array}{l}-1.598^{\star \star *} \\
(-10.45)\end{array}$ & $\begin{array}{l}-1.570^{\star * *} \\
(-8.97)\end{array}$ \\
\hline $\begin{array}{l}\text { Consumer loan } \\
\text { dummy }\end{array}$ & $\begin{array}{l}0.787^{\star \star \star} \\
(4.53)\end{array}$ & $\begin{array}{l}0.666^{\star \star \star} \\
(3.44)\end{array}$ & $\begin{array}{l}0.801^{\star \star \star} \\
(4.60)\end{array}$ & $\begin{array}{l}0.809^{\star \star \star} \\
(4.64)\end{array}$ & $\begin{array}{l}0.851^{\star \star \star} \\
(4.83)\end{array}$ & $\begin{array}{l}0.836^{\star \star \star} \\
(4.74)\end{array}$ & $\begin{array}{l}0.950^{\star \star \star} \\
(5.08)\end{array}$ \\
\hline LTV & & & $\begin{array}{l}0.357^{\star \star \star} \\
(3.63)\end{array}$ & $\begin{array}{l}0.552^{\star \star \star} \\
(4.51)\end{array}$ & $\begin{array}{l}0.474^{\star \star \star} \\
(3.53)\end{array}$ & $\begin{array}{l}0.500^{\star \star \star} \\
(3.67)\end{array}$ & $\begin{array}{l}0.510^{\star \star \star} \\
(3.79)\end{array}$ \\
\hline (log) size of the loan & & & & $\begin{array}{l}-0.339 * * \\
(-2.61)\end{array}$ & $\begin{array}{l}-0.292^{*} \\
(-2.16)\end{array}$ & $\begin{array}{l}-0.308^{*} \\
(-2.27)\end{array}$ & $\begin{array}{l}-0.305^{\star} \\
(-2.26)\end{array}$ \\
\hline Above average wage & & & & & $\begin{array}{l}-0.170 \\
(-0.94)\end{array}$ & & \\
\hline Below average wage & & & & & $\begin{array}{l}0.143 \\
(0.93)\end{array}$ & & \\
\hline Log income & & & & & & $\begin{array}{l}-0.108 \\
(-0.90)\end{array}$ & \\
\hline $\begin{array}{l}\text { Bank dummies } \\
\text { Origination year } \\
\text { Region dummies }\end{array}$ & & & & & & & $\begin{array}{l}\text { Yes } \\
\text { Yes } \\
\text { Yes }\end{array}$ \\
\hline _cons & $\begin{array}{l}-7.480 \text { *** } \\
(-20.98)\end{array}$ & $\begin{array}{l}-7.681^{\star \star *} \\
(-19.18)\end{array}$ & $\begin{array}{l}-7.934^{\star \star *} \\
(-20.84)\end{array}$ & $\begin{array}{l}-4.163^{\star \star} \\
(-2.80)\end{array}$ & $\begin{array}{l}-4.368^{\star \star} \\
(-2.90)\end{array}$ & $\begin{array}{l}-3.516^{\star} \\
(-2.12)\end{array}$ & $\begin{array}{l}-4.760 * * \\
(-2.99)\end{array}$ \\
\hline $\mathrm{N}$ & 200,598 & 191,932 & 200,598 & 200,598 & 200,598 & 200,598 & 198,843 \\
\hline
\end{tabular}


Table 5. Mortgage Model-Marginal Effects

\begin{tabular}{|c|c|c|c|c|c|c|c|}
\hline & (1) & $(2)$ & (3) & (4) & (5) & (6) & (7) \\
\hline range $=1$ & $\begin{array}{l}0.0235 \\
(1.283)\end{array}$ & $\begin{array}{c}1.315 \\
(1.421)\end{array}$ & $\begin{array}{l}0.0485 \\
(1.285)\end{array}$ & $\begin{array}{l}0.0578 \\
(1.287)\end{array}$ & $\begin{array}{l}-0.160 \\
(1.299)\end{array}$ & $\begin{array}{l}-0.136 \\
(1.305)\end{array}$ & $\begin{array}{c}0.161 \\
(1.286)\end{array}$ \\
\hline range $=2$ & $\begin{array}{c}0.245 \\
(0.722)\end{array}$ & $\begin{array}{c}1.010 \\
(0.805)\end{array}$ & $\begin{array}{c}0.294 \\
(0.723)\end{array}$ & $\begin{array}{c}0.326 \\
(0.724)\end{array}$ & $\begin{array}{c}-0.00114 \\
(0.761)\end{array}$ & $\begin{array}{l}0.0858 \\
(0.773)\end{array}$ & $\begin{array}{c}0.415 \\
(0.725)\end{array}$ \\
\hline range $=3$ & $\begin{array}{c}1.435^{\star \star \star} \\
(0.406)\end{array}$ & $\begin{array}{c}1.874^{\star \star \star} \\
(0.454)\end{array}$ & $\begin{array}{c}1.874^{\star \star \star} \\
(0.407)\end{array}$ & $\begin{array}{c}1.532^{\star \star \star} \\
(0.408)\end{array}$ & $\begin{array}{c}1.250^{\star \star *} \\
(0.450)\end{array}$ & $\begin{array}{c}1.332^{\star \star \star} \\
(0.465)\end{array}$ & $\begin{array}{c}1.558^{\star \star \star} \\
(0.410)\end{array}$ \\
\hline range $=4$ & $\begin{array}{c}1.268^{\star \star \star} \\
(0.308)\end{array}$ & $\begin{array}{c}1.865^{\star \star \star} \\
(0.423)\end{array}$ & $\begin{array}{c}1.338^{\star \star \star} \\
(0.309)\end{array}$ & $\begin{array}{c}1.372^{\star \star \star} \\
(0.310)\end{array}$ & $\begin{array}{c}1.152^{\star \star \star} \\
(0.342)\end{array}$ & $\begin{array}{c}1.213^{\star \star \star} \\
(0.357)\end{array}$ & $\begin{array}{c}1.369^{\star \star \star} \\
(0.311)\end{array}$ \\
\hline range $=5$ & $\begin{array}{c}0.681^{\star * *} \\
(0.131)\end{array}$ & & $\begin{array}{c}0.743^{\star \star \star} \\
(0.132)\end{array}$ & $\begin{array}{c}0.771^{\star \star \star} \\
(0.133)\end{array}$ & $\begin{array}{c}0.662^{\star \star \star} \\
(0.153)\end{array}$ & $\begin{array}{c}0.691^{\star \star \star} \\
(0.161)\end{array}$ & $\begin{array}{c}0.757^{\star \star \star} \\
(0.135)\end{array}$ \\
\hline Observations & 200,598 & 191,932 & 200,598 & 200,598 & 200,598 & 200,598 & 198,843 \\
\hline
\end{tabular}

Source: NBR and IMF staff estimates.

Note: The point estimates indicate percentage increase in PD for a 1 percentage point increase in DSTI.

Standard errors in parentheses, ${ }^{\star * \star}$ p $0.01,{ }^{* \star}$ p $0.05,{ }^{*}$ p 0.1 . 
Table 6. Mortgage Model-Linear in DSTI

\begin{tabular}{|c|c|c|c|c|c|c|c|}
\hline & (1) & $(2)$ & (3) & (4) & (5) & (6) & (7) \\
\hline DSTI & $\begin{array}{l}0.775^{\star \star \star} \\
(9.08)\end{array}$ & $\begin{array}{l}2.114^{\star \star \star} \\
(7.58)\end{array}$ & $\begin{array}{l}0.837^{\star \star \star} \\
(9.56)\end{array}$ & $\begin{array}{l}0.864^{\star \star \star} \\
(9.81)\end{array}$ & $\begin{array}{l}0.692^{\star \star \star} \\
(6.40)\end{array}$ & $\begin{array}{l}0.692^{\star \star \star} \\
(6.40)\end{array}$ & $\begin{array}{l}0.837^{\star \star \star} \\
(9.02)\end{array}$ \\
\hline residual maturity & $\begin{array}{l}0.0287^{*} \\
(2.53)\end{array}$ & $\begin{array}{l}0.0289^{\star} \\
(2.34)\end{array}$ & $\begin{array}{l}0.0331^{\star *} \\
(2.91)\end{array}$ & $\begin{array}{l}0.0355^{\star \star} \\
(3.10)\end{array}$ & $\begin{array}{l}0.0299 * \star \\
(2.58)\end{array}$ & $\begin{array}{l}0.0300^{\star \star} \\
(2.59)\end{array}$ & 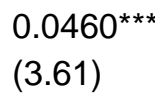 \\
\hline euro denominated & $\begin{array}{l}0.626^{\star \star \star} \\
(4.74)\end{array}$ & $\begin{array}{l}0.602^{\star \star \star} \\
(4.19)\end{array}$ & $\begin{array}{l}0.629 * \star \star \\
(4.77)\end{array}$ & $\begin{array}{l}0.626^{\star \star \star} \\
(4.76)\end{array}$ & $\begin{array}{l}0.644^{\star \star \star} \\
(4.88)\end{array}$ & $\begin{array}{l}0.642^{\star \star \star} \\
(4.87)\end{array}$ & $\begin{array}{l}0.212 \\
(1.07)\end{array}$ \\
\hline CHF denominated & $\begin{array}{l}1.428^{\star * \star} \\
(5.95)\end{array}$ & $\begin{array}{l}1.299 * \star \star \\
(4.81)\end{array}$ & $\begin{array}{l}1.348^{\star \star *} \\
(5.60)\end{array}$ & $\begin{array}{l}1.309^{* \star *} \\
(5.43)\end{array}$ & $\begin{array}{l}1.333^{\star \star \star} \\
(5.51)\end{array}$ & $\begin{array}{l}1.332^{\star \star \star} \\
(5.51)\end{array}$ & $\begin{array}{l}1.124^{\star \star} \\
(3.27)\end{array}$ \\
\hline First home dummy & $\begin{array}{l}-1.539 \star \star \star \\
(-10.11)\end{array}$ & $\begin{array}{l}-1.654^{\star * *} \\
(-10.09)\end{array}$ & $\begin{array}{l}-1.576^{\star \star \star} \\
(-10.32)\end{array}$ & $\begin{array}{l}-1.588^{\star \star *} \\
(-10.40)\end{array}$ & $\begin{array}{l}-1.593^{\star \star *} \\
(-10.43)\end{array}$ & $\begin{array}{l}-1.592^{\star \star \star} \\
(-10.42)\end{array}$ & $\begin{array}{l}-1.553^{\star \star *} \\
(-8.89)\end{array}$ \\
\hline $\begin{array}{l}\text { Consumer loan } \\
\text { dummy }\end{array}$ & $\begin{array}{l}0.811^{\star \star *} \\
(4.70)\end{array}$ & $\begin{array}{l}0.637^{\star \star \star} \\
(3.31)\end{array}$ & $\begin{array}{l}0.828^{\star \star \star} \\
(4.78)\end{array}$ & $\begin{array}{l}0.837^{\star \star \star} \\
(4.83)\end{array}$ & $\begin{array}{l}0.895^{\star \star \star} \\
(5.16)\end{array}$ & $\begin{array}{l}0.896^{\star \star \star} \\
(5.17)\end{array}$ & $\begin{array}{l}0.979 * * \star \\
(5.26)\end{array}$ \\
\hline LTV & & & $\begin{array}{l}0.348^{\star \star \star} \\
(3.55)\end{array}$ & $\begin{array}{l}0.534^{\star \star \star} \\
(4.39)\end{array}$ & $\begin{array}{l}0.393^{\star \star} \\
(2.95)\end{array}$ & $\begin{array}{l}0.396^{\star *} \\
(3.00)\end{array}$ & $\begin{array}{l}0.487^{\star \star \star} \\
(3.64)\end{array}$ \\
\hline (log) size of the loan & & & & $\begin{array}{l}-0.327^{*} \\
(-2.53)\end{array}$ & $\begin{array}{l}-0.241 \\
(-1.79)\end{array}$ & $\begin{array}{l}-0.243 \\
(-1.81)\end{array}$ & $\begin{array}{l}-0.288^{*} \\
(-2.14)\end{array}$ \\
\hline Above average wage & & & & & $\begin{array}{l}-0.243 \\
(-1.40)\end{array}$ & & \\
\hline Below average wage & & & & & $\begin{array}{l}0.310^{*} \\
(2.10)\end{array}$ & & \\
\hline Log income & & & & & & $\begin{array}{l}-0.488^{\star \star} \\
(-3.07)\end{array}$ & \\
\hline $\begin{array}{l}\text { Bank dummies } \\
\text { Origination year } \\
\text { Region dummies }\end{array}$ & & & & & & & $\begin{array}{l}\text { Yes } \\
\text { Yes } \\
\text { Yes }\end{array}$ \\
\hline _cons & $\begin{array}{l}-7.479 \star \star \star \\
(-27.74)\end{array}$ & $\begin{array}{l}-7.907^{\star \star \star} \\
(-25.11)\end{array}$ & $\begin{array}{l}-7.927^{\star \star \star} \\
(-26.37)\end{array}$ & $\begin{array}{l}-4.289 * * \\
(-2.93)\end{array}$ & $\begin{array}{l}-5.085^{\text {}} \\
(-3.36)\end{array}$ & $\begin{array}{l}-4.748^{\star *} \\
(-3.18)\end{array}$ & $\begin{array}{l}-4.886^{\star *} \\
(-3.11)\end{array}$ \\
\hline $\mathrm{N}$ & 200598 & 191932 & 200598 & 200598 & 200598 & 200598 & 198843 \\
\hline
\end{tabular}

Source: NBR and IMF staff estimates.

Note: Standard errors in parentheses, ${ }^{* *} p<0.01,{ }^{* *} p<0.05,{ }^{*} p<0.1$. 
Table 7. Mortgage Model—Including Debtors with Multiple Loans

\begin{tabular}{|c|c|c|c|c|c|c|}
\hline & (1) & (2) & (3) & (4) & (5) & (6) \\
\hline Range1\#dti & $\begin{array}{l}-1.707 \\
(-1.47)\end{array}$ & $\begin{array}{l}0.381 \\
(0.27)\end{array}$ & $\begin{array}{l}-1.719 \\
(-1.48)\end{array}$ & $\begin{array}{l}-1.660 \\
(-1.45)\end{array}$ & $\begin{array}{l}-2.199 \\
(-1.87)\end{array}$ & $\begin{array}{l}-1.412 \\
(-1.22)\end{array}$ \\
\hline Range2\#dti & $\begin{array}{l}-0.809 \\
(-1.25)\end{array}$ & $\begin{array}{l}0.365 \\
(0.46)\end{array}$ & $\begin{array}{l}-0.825 \\
(-1.28)\end{array}$ & $\begin{array}{l}-1.421^{*} \\
(-2.13)\end{array}$ & $\begin{array}{l}-1.453^{*} \\
(-2.04)\end{array}$ & $\begin{array}{l}-0.654 \\
(-1.01)\end{array}$ \\
\hline Range3\#dti & $\begin{array}{l}0.957^{\star \star} \\
(2.69)\end{array}$ & $\begin{array}{l}1.610^{\star \star \star \star} \\
(3.65)\end{array}$ & $\begin{array}{l}0.944^{\star \star} \\
(2.65)\end{array}$ & $\begin{array}{l}0.302 \\
(0.77)\end{array}$ & $\begin{array}{l}0.408 \\
(0.93)\end{array}$ & $\begin{array}{l}0.970 * \star \\
(2.72)\end{array}$ \\
\hline Range4\#dti & $\begin{array}{l}1.110^{\star * *} \\
(4.31)\end{array}$ & $\begin{array}{l}1.611^{\star \star \star} \\
(4.01)\end{array}$ & $\begin{array}{l}1.099 * * * \\
(4.24)\end{array}$ & $\begin{array}{l}0.576^{\star} \\
(2.00)\end{array}$ & $\begin{array}{l}0.664^{*} \\
(2.02)\end{array}$ & $\begin{array}{l}1.066^{\star \star \star} \\
(4.11)\end{array}$ \\
\hline Range5\#dti & $\begin{array}{l}0.582^{\star \star *} \\
(6.37)\end{array}$ & & $\begin{array}{l}0.575^{\star \star \star} \\
(6.16)\end{array}$ & $\begin{array}{l}0.314^{\star \star} \\
(2.73)\end{array}$ & $\begin{array}{l}0.285 \\
(1.72)\end{array}$ & $\begin{array}{l}0.543^{\star \star \star} \\
(5.77)\end{array}$ \\
\hline residual maturity & $\begin{array}{l}-0.0165 \\
(-1.93)\end{array}$ & $\begin{array}{l}-0.0222^{\star} \\
(-2.10)\end{array}$ & $\begin{array}{l}-0.0177 \\
(-1.95)\end{array}$ & $\begin{array}{l}-0.0314^{\star *} \\
(-3.21)\end{array}$ & $\begin{array}{l}-0.0299 * \star \\
(-2.79)\end{array}$ & $\begin{array}{l}0.0108 \\
(1.02)\end{array}$ \\
\hline euro denominated & $\begin{array}{l}0.491^{\star \star \star} \\
(4.42)\end{array}$ & $\begin{array}{l}0.489^{\star \star \star} \\
(3.62)\end{array}$ & $\begin{array}{l}0.488^{\star \star \star} \\
(4.39)\end{array}$ & $\begin{array}{l}0.497^{\star \star \star} \\
(4.46)\end{array}$ & $\begin{array}{l}0.487^{\star \star \star} \\
(4.37)\end{array}$ & $\begin{array}{l}0.171 \\
(0.92)\end{array}$ \\
\hline CHF denominated & $\begin{array}{l}1.628^{\star * *} \\
(7.89)\end{array}$ & $\begin{array}{l}1.782^{\star \star \star} \\
(7.11)\end{array}$ & $\begin{array}{l}1.614^{* * *} \\
(7.71)\end{array}$ & $\begin{array}{l}1.577^{\star \star \star} \\
(7.53)\end{array}$ & $\begin{array}{l}1.596^{\star \star \star} \\
(7.62)\end{array}$ & $\begin{array}{l}0.764^{*} \\
(2.51)\end{array}$ \\
\hline First home dummy & $\begin{array}{l}0.0852 \\
(0.60)\end{array}$ & $\begin{array}{l}-0.370 \\
(-1.74)\end{array}$ & $\begin{array}{l}0.0823 \\
(0.57)\end{array}$ & $\begin{array}{l}0.0991 \\
(0.69)\end{array}$ & $\begin{array}{l}0.0914 \\
(0.64)\end{array}$ & $\begin{array}{l}-0.0224 \\
(-0.15)\end{array}$ \\
\hline $\begin{array}{l}\text { Consumer loan } \\
\text { dummy }\end{array}$ & $\begin{array}{l}0.297^{\star} \\
(2.15)\end{array}$ & $\begin{array}{l}0.178 \\
(1.03)\end{array}$ & $\begin{array}{l}0.276 \\
(1.86)\end{array}$ & $\begin{array}{l}0.235 \\
(1.59)\end{array}$ & $\begin{array}{l}0.222 \\
(1.48)\end{array}$ & $\begin{array}{l}0.603^{\star \star \star} \\
(3.74)\end{array}$ \\
\hline Multiple loan dummy & $\begin{array}{l}-0.228 \\
(-0.73)\end{array}$ & $\begin{array}{l}-0.0103 \\
(-0.03)\end{array}$ & $\begin{array}{l}-0.266 \\
(-0.81)\end{array}$ & $\begin{array}{l}-0.351 \\
(-1.07)\end{array}$ & $\begin{array}{l}-0.336 \\
(-1.02)\end{array}$ & $\begin{array}{l}-0.154 \\
(-0.47)\end{array}$ \\
\hline (log) size of the loan & & & $\begin{array}{l}0.0364 \\
(0.40)\end{array}$ & $\begin{array}{l}0.263^{\star} \\
(2.44)\end{array}$ & $\begin{array}{l}0.226 \\
(1.77)\end{array}$ & $\begin{array}{l}0.0729 \\
(0.75)\end{array}$ \\
\hline Above average wage & & & & $\begin{array}{l}-0.434^{\star} \\
(-2.41)\end{array}$ & & \\
\hline Below average wage & & & & $\begin{array}{l}0.413^{\star \star} \\
(2.70)\end{array}$ & & \\
\hline Log income & & & & & $\begin{array}{l}-0.232^{\star} \\
(-2.17)\end{array}$ & \\
\hline _cons & $\begin{array}{l}-6.762^{\star \star *} \\
(-23.09)\end{array}$ & $\begin{array}{l}-7.039 \star \star \star \\
(-18.80)\end{array}$ & $\begin{array}{l}-7.156^{\star \star *} \\
(-6.87)\end{array}$ & $\begin{array}{l}-9.451^{\star \star *} \\
(-7.90)\end{array}$ & $\begin{array}{l}-7.111^{* \star *} \\
(-6.81)\end{array}$ & $\begin{array}{l}-8.349^{\star \star *} \\
(-7.01)\end{array}$ \\
\hline $\mathrm{N}$ & 226263 & 203527 & 226263 & 226263 & 226263 & 223996 \\
\hline
\end{tabular}

Source: NBR and IMF staff estimates.

Note: Standard errors in parentheses, ${ }^{* \star} p<0.01,{ }^{* \star} p<0.05,{ }^{*} p<0.1$. 
Table 8. Mortgage Model—Marginal Effects: Including Debtors with Multiple Loans

\begin{tabular}{|c|c|c|c|c|c|c|c|}
\hline & $(1)$ & $(2)$ & (3) & $(4)$ & (5) & (6) & $(7)$ \\
\hline range $=1$ & $\begin{array}{l}-1.705 \\
(1.158)\end{array}$ & $\begin{array}{c}0.381 \\
(1.398)\end{array}$ & $\begin{array}{l}-1.717 \\
(1.158)\end{array}$ & $\begin{array}{l}-1.658 \\
(1.141)\end{array}$ & $\begin{array}{l}-2.197^{\star} \\
(1.174)\end{array}$ & $\begin{array}{l}-1.705 \\
(1.158)\end{array}$ & $\begin{array}{c}0.381 \\
(1.398)\end{array}$ \\
\hline range $=2$ & $\begin{array}{l}-0.809 \\
(0.645)\end{array}$ & $\begin{array}{c}0.365 \\
(0.791)\end{array}$ & $\begin{array}{l}-0.825 \\
(0.647)\end{array}$ & $\begin{array}{c}-1.420^{* *} \\
(0.667)\end{array}$ & $\begin{array}{c}-1.451^{\star *} \\
(0.710)\end{array}$ & $\begin{array}{l}-0.809 \\
(0.645)\end{array}$ & $\begin{array}{c}0.365 \\
(0.791)\end{array}$ \\
\hline range $=3$ & $\begin{array}{c}0.954^{\star \star \star} \\
(0.354)\end{array}$ & $\begin{array}{c}1.606^{\star \star \star} \\
(0.440)\end{array}$ & $\begin{array}{c}0.941^{* * *} \\
(0.356)\end{array}$ & $\begin{array}{c}0.301 \\
(0.389)\end{array}$ & $\begin{array}{c}0.407 \\
(0.435)\end{array}$ & $\begin{array}{c}0.954^{\star \star *} \\
(0.354)\end{array}$ & $\begin{array}{c}1.606^{\star \star \star} \\
(0.440)\end{array}$ \\
\hline range $=4$ & $\begin{array}{c}1.105^{\star \star *} \\
(0.256)\end{array}$ & $\begin{array}{c}1.604^{\star * *} \\
(0.399)\end{array}$ & $\begin{array}{c}1.094^{* * *} \\
(0.257)\end{array}$ & $\begin{array}{l}0.574^{\star *} \\
(0.287)\end{array}$ & $\begin{array}{l}0.661^{* *} \\
(0.327)\end{array}$ & $\begin{array}{c}1.105^{* \star *} \\
(0.256)\end{array}$ & $\begin{array}{c}1.604^{\star * \star} \\
(0.399)\end{array}$ \\
\hline range $=5$ & $\begin{array}{l}0.578^{\star * *} \\
(0.0907)\end{array}$ & & $\begin{array}{l}0.571^{* * *} \\
(0.0926)\end{array}$ & $\begin{array}{c}0.312^{\star \star *} \\
(0.114)\end{array}$ & $\begin{array}{l}0.283^{\star} \\
(0.164)\end{array}$ & $\begin{array}{l}0.578^{\star \star *} \\
(0.0907)\end{array}$ & \\
\hline Observations & 226,263 & 203,527 & 226,263 & 226,263 & 226,263 & 226,263 & 203,527 \\
\hline
\end{tabular}

Source: NBR and IMF staff estimates.

Note: The point estimates indicate percentage increase in PD for a 1 percentage point increase in DSTI.

Standard errors in parentheses, ${ }^{* *}$ p $0.01,{ }^{* *}$ p $0.05,{ }^{*} p 0.1$. 
Table 9. DSTI Ranges for Consumer Loans

\begin{tabular}{llll} 
Indicator & DSTI (percent) & Number of loans & Share of total \\
\hline Range $=1$ & {$[0,15)$} & 190,176 & $40.6 \%$ \\
Range $=2$ & {$[15,30)$} & 126,036 & $26.9 \%$ \\
Range $=3$ & {$[30,50)$} & 107,571 & $23.0 \%$ \\
Range $=4$ & {$[50,70)$} & 26,651 & $5.7 \%$ \\
Range $=5$ & $>70$ & 17,535 & $3.7 \%$ \\
Total & & 467,969 & $100.0 \%$ \\
\hline
\end{tabular}

Source: NBR and IMF staff estimates.

Note: We assess the marginal impact of DSTI on consumer PDs for the ranges defined in this table. The table also indicates the distribution of consumer loans in our sample across different DSTI ranges. 


\section{Table 10. Consumer Model}

\begin{tabular}{|c|c|c|c|c|c|c|c|}
\hline & (1) & (2) & (3) & (4) & (5) & (6) & (7) \\
\hline Range 1\#dti & $\begin{array}{l}0.343 \\
(0.99)\end{array}$ & $\begin{array}{l}0.535 \\
(1.55)\end{array}$ & $\begin{array}{l}1.118^{\star \star} \\
(2.95)\end{array}$ & $\begin{array}{c}1.418^{\star \star \star} \\
(4.08)\end{array}$ & $\begin{array}{l}0.0349 \\
(0.10)\end{array}$ & $\begin{array}{l}-0.492 \\
(-1.33)\end{array}$ & $\begin{array}{l}-0.264 \\
(-0.71)\end{array}$ \\
\hline Range2\#dti & $\begin{array}{l}0.405 \\
(1.93)\end{array}$ & $\begin{array}{l}0.815 \\
(3.91)\end{array}$ & $\begin{array}{c}1.164^{\star \star \star} \\
(5.07)\end{array}$ & $\begin{array}{c}2.316^{\star \star \star} \\
(10.87)\end{array}$ & $\begin{array}{l}0.832 \\
(3.61)\end{array}$ & $\begin{array}{l}0.159 \\
(0.64)\end{array}$ & $\begin{array}{l}0.234 \\
(0.93)\end{array}$ \\
\hline Range3\#dti & $\begin{array}{c}0.627^{\star \star *} \\
(4.63)\end{array}$ & $\begin{array}{c}1.091^{\star \star \star} \\
(8.11)\end{array}$ & $\begin{array}{c}1.318^{\star \star \star} \\
(8.90)\end{array}$ & $\begin{array}{c}2.684^{\star \star \star} \\
(18.56)\end{array}$ & $\begin{array}{c}1.487^{\star \star \star} \\
(9.25)\end{array}$ & $\begin{array}{c}0.912^{\star \star \star} \\
(5.16)\end{array}$ & $\begin{array}{c}0.856^{\star \star \star} \\
(4.75)\end{array}$ \\
\hline Range4\#dti & $\begin{array}{c}0.538^{\star \star \star *} \\
(5.10)\end{array}$ & $\begin{array}{c}0.882^{\star \star \star} \\
(8.36)\end{array}$ & $\begin{array}{c}1.032^{\star \star \star} \\
(9.11)\end{array}$ & $\begin{array}{l}2.224^{\star \star \star} \\
(19.38)\end{array}$ & $\begin{array}{c}1.246^{\star \star \star *} \\
(9.75)\end{array}$ & $\begin{array}{c}0.786^{\star \star \star *} \\
(5.59)\end{array}$ & $\begin{array}{c}0.661^{\star \star \star} \\
(4.59)\end{array}$ \\
\hline Range5\#dti & $\begin{array}{c}0.301^{\star \star \star} \\
(5.74)\end{array}$ & $\begin{array}{c}0.445^{\star \star \star} \\
(8.82)\end{array}$ & $\begin{array}{c}0.766^{\star \star \star} \\
(7.90)\end{array}$ & $\begin{array}{l}1.013^{\star \star \star} \\
(21.48)\end{array}$ & $\begin{array}{l}0.616^{\star \star \star} \\
(10.32)\end{array}$ & $\begin{array}{c}0.363^{\star \star \star} \\
(5.05)\end{array}$ & $\begin{array}{c}0.313^{\star \star \star} \\
(4.07)\end{array}$ \\
\hline $\begin{array}{l}\text { residual } \\
\text { maturity }\end{array}$ & $\begin{array}{c}0.212^{\star \star \star} \\
(21.94)\end{array}$ & $\begin{array}{c}0.110^{\star \star *} \\
(11.22)\end{array}$ & $\begin{array}{c}0.109^{\star \star \star} \\
(10.99)\end{array}$ & $\begin{array}{l}0.304^{\star \star \star} \\
(25.55)\end{array}$ & $\begin{array}{c}0.195^{\star \star \star} \\
(14.79)\end{array}$ & $\begin{array}{l}0.148^{\star \star \star} \\
(10.27)\end{array}$ & $\begin{array}{c}0.285^{\star \star \star} \\
(14.85)\end{array}$ \\
\hline Borrower age & & $\begin{array}{c}- \\
0.0440 * \star \\
(-48.26)\end{array}$ & $\begin{array}{c}- \\
0.0445^{\star \star \star} \\
(-48.39)\end{array}$ & $\begin{array}{c}- \\
0.0450 * \star \\
(-49.94)\end{array}$ & $\begin{array}{c}- \\
0.0450^{\star \star \star} \\
(-50.57)\end{array}$ & $\begin{array}{c}- \\
0.4053^{\star \star *} \\
(-51.17)\end{array}$ & $\begin{array}{c}-0.459 * \star \star \\
(-53.32)\end{array}$ \\
\hline $\begin{array}{l}(\log ) \text { size of the } \\
\text { loan }\end{array}$ & & & & $\begin{array}{c}-0.572^{\star \star \star} \\
(-27.86)\end{array}$ & $\begin{array}{c}-0.262^{\star *} \\
(-9.84)\end{array}$ & $\begin{array}{c}-0.117^{\star \star \star} \\
(-3.68)\end{array}$ & $\begin{array}{c}-0.0937^{\star \star} \\
(-2.84)\end{array}$ \\
\hline $\begin{array}{l}\text { Above average } \\
\text { wage }\end{array}$ & & & & & $\begin{array}{c}-0.367^{\star \star *} \\
(-5.20)\end{array}$ & & \\
\hline $\begin{array}{l}\text { Below average } \\
\text { wage }\end{array}$ & & & & & $\begin{array}{l}0.601^{\star \star \star} \\
(18.69)\end{array}$ & & \\
\hline Log income & & & & & & $\begin{array}{c}-0.771^{\star \star \star} \\
(-21.51)\end{array}$ & $\begin{array}{c}-0.785^{\star \star \star} \\
(-20.93)\end{array}$ \\
\hline Bank dummies & & & & & & & Yes \\
\hline $\begin{array}{l}\text { Origination year } \\
\text { dummies }\end{array}$ & & & & & & & Yes \\
\hline $\begin{array}{l}\text { Region } \\
\text { dummies }\end{array}$ & & & & & & & Yes \\
\hline $\mathrm{N}$ & 467,969 & 467,969 & 461,877 & 467,969 & 467,969 & 467,969 & 467,806 \\
\hline
\end{tabular}

Source: NBR and IMF staff estimates.

Note: Standard errors in parentheses, ${ }^{* *} p<0.01,{ }^{* *} p<0.05,{ }^{*} p<0.1$. 
Table 11. Consumer Model

\begin{tabular}{|c|c|c|c|c|c|c|c|}
\hline & $(1)$ & (2) & (3) & (4) & (5) & (6) & (7) \\
\hline Range $=1$ & $\begin{array}{c}0.337 \\
(0.340)\end{array}$ & $\begin{array}{c}0.525 \\
(0.339)\end{array}$ & $\begin{array}{c}1.098^{\star \star \star} \\
(0.373)\end{array}$ & $\begin{array}{c}1.392^{\star \star \star} \\
(0.341)\end{array}$ & $\begin{array}{l}0.0343 \\
(0.353)\end{array}$ & $\begin{array}{c}-0.483 \\
(0.353)\end{array}$ & $\begin{array}{l}-0.260 \\
(0.366)\end{array}$ \\
\hline Range $=2$ & $\begin{array}{l}0.397^{\star} \\
(0.205)\end{array}$ & $\begin{array}{c}0.799 * \star * \\
(0.204)\end{array}$ & $\begin{array}{c}1.141^{\star \star \star} \\
(0.225)\end{array}$ & $\begin{array}{c}2.271^{\star \star \star} \\
(0.209)\end{array}$ & $\begin{array}{c}0.815^{\star \star \star} \\
(0.226)\end{array}$ & $\begin{array}{c}0.156 \\
(0.242)\end{array}$ & $\begin{array}{c}0.229 \\
(0.246)\end{array}$ \\
\hline Range $=3$ & $\begin{array}{l}0.613^{\star \star \star} \\
(0.132)\end{array}$ & $\begin{array}{l}1.066^{\star \star *} \\
(0.131)\end{array}$ & $\begin{array}{l}1.288^{\star \star *} \\
(0.145)\end{array}$ & $\begin{array}{l}2.622^{\star \star \star} \\
(0.141)\end{array}$ & $\begin{array}{l}1.453^{\star \star \star} \\
(0.157)\end{array}$ & $\begin{array}{l}0.891^{\star \star \star} \\
(0.173)\end{array}$ & $\begin{array}{l}0.836^{\star \star \star} \\
(0.176)\end{array}$ \\
\hline Range $=4$ & $\begin{array}{c}0.525^{\star \star \star} \\
(0.103)\end{array}$ & $\begin{array}{c}0.860^{\star \star \star} \\
(0.102)\end{array}$ & $\begin{array}{c}1.006^{\star \star \star} \\
(0.110)\end{array}$ & $\begin{array}{c}2.168^{\star \star \star} \\
(0.111)\end{array}$ & $\begin{array}{c}1.215^{\star \star \star} \\
(0.124)\end{array}$ & $\begin{array}{c}0.766^{\star \star \star} \\
(0.137)\end{array}$ & $\begin{array}{c}0.645^{\star \star \star} \\
(0.140)\end{array}$ \\
\hline Range $=5$ & $\begin{array}{l}0.293^{\star \star \star} \\
(0.0509)\end{array}$ & $\begin{array}{l}0.434^{\star \star \star} \\
(0.0490)\end{array}$ & $\begin{array}{l}0.746^{\star \star \star} \\
(0.0936)\end{array}$ & $\begin{array}{l}0.992^{\star \star *} \\
(0.0457)\end{array}$ & $\begin{array}{l}0.601^{\star \star *} \\
(0.0580)\end{array}$ & $\begin{array}{l}0.354^{\star \star \star} \\
(0.0699)\end{array}$ & $\begin{array}{l}0.305^{\star \star \star} \\
(0.0747)\end{array}$ \\
\hline Observations & 467,969 & 467,969 & 461,877 & 467,969 & 467,969 & 467,969 & 467,806 \\
\hline
\end{tabular}

Source: NBR and IMF staff estimates.

Note: The point estimates indicate percentage increase in PD for a 1 percentage point increase in DSTI.

Standard errors in parentheses, ${ }^{\star * *}$ p $0.01,{ }^{* *}$ p $0.05,{ }^{*}$ p 0.1 .

Table 12. Shock Absorbency of a Loan Originated at DSTI of 40 percent

Domestic Loan

FX Loan

\begin{tabular}{lllccc}
\hline & Scenario 1 & Scenario 2 & Scenario 3 & Scenario 4 & Scenario 5 \\
Interest Rate shock & $2.0 \%$ & $0.0 \%$ & $1.5 \%$ & $0.0 \%$ & $1.5 \%$ \\
Income Shock & $0.0 \%$ & $20.0 \%$ & $5.0 \%$ & $0.0 \%$ & $5.0 \%$ \\
FX shocks & $0.0 \%$ & $0.0 \%$ & $0.0 \%$ & $60.0 \%$ & $30.0 \%$ \\
& & & & & \\
Modified DSTI & $50.2 \%$ & $50.0 \%$ & $50.1 \%$ & $32.0 \%$ & $32.5 \%$ \\
& & & & & \\
Annuity factor original & $0.48 \%$ & $0.48 \%$ & $0.48 \%$ & $0.48 \%$ & $0.48 \%$ \\
Annuity factor shocked & $0.60 \%$ & $0.60 \%$ & $0.60 \%$ & $0.76 \%$ & $0.78 \%$ \\
\hline
\end{tabular}

Source: NBR and IMF staff estimates.

Note: This table presents the combination of shocks that could lead to an increase in DSTI from 40 to 50 percent (for a leu-denominated loan) and from 20 to 32 percent (for an FX denominated loan). An FX (mortgage) loan with a DSTI of 32 percent has the same probability of default as an identical leu-denominated (mortgage) loan with a DSTI of 50 percent. 
Table 13. Impact on Mortgage PD's, by DSTI

\begin{tabular}{|c|c|c|c|c|c|c|c|c|c|c|}
\hline & & \multicolumn{3}{|c|}{ Total } & \multicolumn{3}{|c|}{ Domestic Currency } & \multicolumn{3}{|c|}{$\mathrm{FX}$} \\
\hline & & Actual & w/ limit & $\%$ change & Actual & w/ limit & $\%$ change & Actual & w/ limit & $\%$ change \\
\hline Range 1 & Mean & $0.32 \%$ & $0.32 \%$ & $2.2 \%$ & $0.23 \%$ & $0.23 \%$ & $0.0 \%$ & $0.39 \%$ & $0.41 \%$ & $3.5 \%$ \\
\hline DSTI $<30$ & Median & $0.19 \%$ & $0.20 \%$ & $3.2 \%$ & $0.13 \%$ & $0.13 \%$ & $0.0 \%$ & $0.22 \%$ & $0.23 \%$ & $4.0 \%$ \\
\hline $\begin{array}{l}\text { Range } 2 \\
\text { DSTI: }\end{array}$ & Mean & $0.35 \%$ & $0.37 \%$ & $7.4 \%$ & $0.24 \%$ & $0.24 \%$ & $0.8 \%$ & $0.46 \%$ & $0.51 \%$ & $11.2 \%$ \\
\hline$[30,50)$ & Median & $0.19 \%$ & $0.21 \%$ & $8.8 \%$ & $0.13 \%$ & $0.13 \%$ & $1.0 \%$ & $0.25 \%$ & $0.28 \%$ & $11.3 \%$ \\
\hline $\begin{array}{l}\text { Range } 3 \\
\text { DSTI: }\end{array}$ & Mean & $0.90 \%$ & $0.48 \%$ & $-46.5 \%$ & $0.57 \%$ & $0.28 \%$ & $-50.6 \%$ & $1.20 \%$ & $0.67 \%$ & $-44.7 \%$ \\
\hline$[50,90)$ & Median & $0.49 \%$ & $0.26 \%$ & $-46.2 \%$ & $0.31 \%$ & $0.15 \%$ & $-50.9 \%$ & $0.65 \%$ & $0.35 \%$ & $-45.6 \%$ \\
\hline $\begin{array}{l}\text { Range } 4 \\
\text { DSTI: }\end{array}$ & Mean & $1.51 \%$ & $0.63 \%$ & $-58.1 \%$ & $0.95 \%$ & $0.36 \%$ & $-61.5 \%$ & $1.88 \%$ & $0.81 \%$ & $-56.9 \%$ \\
\hline$[90,120)$ & Median & $0.91 \%$ & $0.37 \%$ & $-59.3 \%$ & $0.55 \%$ & $0.20 \%$ & $-62.9 \%$ & $1.26 \%$ & $0.54 \%$ & $-57.0 \%$ \\
\hline Range 5 & Mean & $2.10 \%$ & $0.92 \%$ & $-56.2 \%$ & $1.37 \%$ & $0.54 \%$ & $-60.5 \%$ & $2.54 \%$ & $1.15 \%$ & $-54.8 \%$ \\
\hline DSTI>120 & Median & $1.50 \%$ & $0.72 \%$ & $-52.1 \%$ & $1.09 \%$ & $0.47 \%$ & $-56.7 \%$ & $1.90 \%$ & $1.00 \%$ & $-47.3 \%$ \\
\hline Total & & $0.50 \%$ & $0.39 \%$ & $-22.6 \%$ & $0.33 \%$ & $0.25 \%$ & $-23.3 \%$ & $0.67 \%$ & $0.52 \%$ & $-22.3 \%$ \\
\hline & & $0.25 \%$ & $0.22 \%$ & $-12.0 \%$ & $0.18 \%$ & $0.14 \%$ & $-23.0 \%$ & & $0.28 \%$ & $-20.3 \%$ \\
\hline
\end{tabular}

Source: NBR and IMF staff estimates.

Note: The table presents counterfactual mortgage PDs, had leu-denominated (FX denominated) mortgage loans been limited to a 40 (20) percent DSTI limit. The counterfactual PDs were derived from our preferred specification presented in Table (4). The average PDs in the sample were calibrated to the means observed as of June 2017. The impact is presented for each DSTI range and split by currency. 
Table 14. Impact on Mortgage PD's, by Income.

\begin{tabular}{|c|c|c|c|c|c|c|c|c|c|c|}
\hline & & \multicolumn{3}{|c|}{ Total } & \multicolumn{3}{|c|}{ Domestic Currency } & \multicolumn{3}{|c|}{$\mathrm{FX}$} \\
\hline \multicolumn{2}{|c|}{ Income Category } & Actual & w/ limit & $\%$ change & Actual & w/ limit & $\%$ change & Actual & w/ limit & $\%$ change \\
\hline \multirow[t]{2}{*}{ Below average } & Mean & $0.70 \%$ & $0.44 \%$ & $-36.7 \%$ & $0.42 \%$ & $0.27 \%$ & $-35.1 \%$ & $1.02 \%$ & $0.64 \%$ & $-37.5 \%$ \\
\hline & Median & $0.36 \%$ & $0.24 \%$ & $-32.3 \%$ & $0.24 \%$ & $0.15 \%$ & $-37.8 \%$ & $0.54 \%$ & $0.34 \%$ & $-36.4 \%$ \\
\hline \multirow{3}{*}{$\begin{array}{l}\text { [average, } \\
2^{\star} \text { average] }\end{array}$} & & & & & & & & & & \\
\hline & Mean & $0.42 \%$ & $0.36 \%$ & $-14.7 \%$ & $0.29 \%$ & $0.24 \%$ & $-17.0 \%$ & $0.57 \%$ & $0.49 \%$ & $-13.5 \%$ \\
\hline & Median & $0.21 \%$ & $0.20 \%$ & $-4.1 \%$ & $0.14 \%$ & $0.13 \%$ & $-3.7 \%$ & $0.25 \%$ & $0.26 \%$ & $1.9 \%$ \\
\hline \multirow[t]{2}{*}{ Above $2 *$ average } & Mean & $0.39 \%$ & $0.36 \%$ & $-6.3 \%$ & $0.27 \%$ & $0.24 \%$ & $-8.6 \%$ & $0.47 \%$ & $0.45 \%$ & $-5.3 \%$ \\
\hline & Median & $0.22 \%$ & $0.23 \%$ & $2.3 \%$ & $0.18 \%$ & $0.16 \%$ & $-9.4 \%$ & $0.25 \%$ & $0.25 \%$ & $2.6 \%$ \\
\hline \multirow[t]{2}{*}{ Total } & Mean & $0.50 \%$ & $0.39 \%$ & $-22.6 \%$ & $0.33 \%$ & $0.25 \%$ & $-23.3 \%$ & $0.67 \%$ & $0.52 \%$ & $-22.3 \%$ \\
\hline & Median & $0.25 \%$ & $0.22 \%$ & $-12.0 \%$ & $0.18 \%$ & $0.14 \%$ & $-23.0 \%$ & $0.35 \%$ & $0.28 \%$ & $-20.3 \%$ \\
\hline
\end{tabular}

Source: NBR and IMF staff estimates.

Note: The table presents counterfactual mortgage PDs, had leu-denominated (FX denominated) mortgage loans been limited to a 40 (20) percent DSTI. The counterfactual PDs were derived from our preferred specification presented in Table (4). The average PDs in the sample were calibrated to the means observed as of June 2017 . The impact is presented for each income group and split by currency. 
Table 15. Impact on Mortgage Volumes, by DSTI

\begin{tabular}{|c|c|c|c|c|c|c|c|c|c|}
\hline & \multicolumn{3}{|c|}{ Total } & \multicolumn{3}{|c|}{ Domestic Currency } & \multicolumn{3}{|c|}{$\mathrm{FX}$} \\
\hline & Actual & w/ limit & $\%$ change & Actual & w/ limit & $\%$ change & Actual & w/ limit & $\%$ change \\
\hline Range 1 & 15.5 & 14.8 & $-5 \%$ & 7.4 & 7.4 & $0 \%$ & 8.0 & 7.3 & $-9 \%$ \\
\hline Range2 & 10.2 & 7.7 & $-25 \%$ & 5.3 & 5.1 & $-4 \%$ & 4.9 & 2.6 & $-47 \%$ \\
\hline \multicolumn{10}{|c|}{ DSTI: $[30,50)$} \\
\hline \multicolumn{10}{|c|}{ DSTI: $[50,90)$} \\
\hline Range 4 & 0.9 & 0.3 & $-72 \%$ & 0.4 & 0.2 & $-60 \%$ & 0.6 & 0.1 & $-80 \%$ \\
\hline \multicolumn{10}{|c|}{ DSTI: $[90,120)$} \\
\hline Range 5 & 0.9 & 0.1 & $-84 \%$ & 0.3 & 0.1 & $-76 \%$ & 0.5 & 0.1 & $-88 \%$ \\
\hline \multicolumn{10}{|c|}{ DSTI>120 } \\
\hline Total & 32.7 & 25.3 & $-23 \%$ & 16.0 & 14.4 & $-10 \%$ & 16.7 & 10.9 & $-35 \%$ \\
\hline
\end{tabular}

Source: NBR and IMF staff estimates.

Note: The table presents counterfactual mortgage PDs, had leu-denominated (FX denominated) mortgage loans been limited to a 40 (20) percent DSTI. The counterfactual PDs were derived from our preferred specification presented in Table (4). The average PDs in the sample were calibrated to the means observed as of June 2017. The impact is presented for each income group and split by currency. 
Table 16. Impact on Mortgage Volumes, by Income

\begin{tabular}{|c|c|c|c|c|c|c|c|c|c|}
\hline & \multicolumn{3}{|c|}{ Total } & \multicolumn{3}{|c|}{ Domestic Currency } & \multicolumn{3}{|c|}{$\mathrm{FX}$} \\
\hline & Actual & w/ limit & $\%$ change & Actual & w/ limit & $\%$ change & Actual & w/ limit & $\%$ change \\
\hline Below average & 10.4 & 6.5 & $-38 \%$ & 5.5 & 4.4 & $-20 \%$ & 4.9 & 2.1 & $-57 \%$ \\
\hline [average, 2*average] & 12.6 & 10.1 & $-20 \%$ & 6.4 & 6.0 & $-6 \%$ & 6.2 & 4.1 & $-34 \%$ \\
\hline Above $2^{\star}$ average & 9.7 & 8.7 & $-10 \%$ & 4.19 & 4.0 & $-3 \%$ & 5.6 & 4.7 & $-15 \%$ \\
\hline Total & 32.7 & 25.3 & $-23 \%$ & 16.0 & 14.4 & $-10 \%$ & 16.7 & 10.9 & $-35 \%$ \\
\hline
\end{tabular}

Source: NBR and IMF staff estimates.

Note: The table presents counterfactual mortgage PDs, had leu-denominated (FX denominated) mortgage loans been limited to a 40 (20) percent DSTI. The counterfactual PDs were derived from our preferred specification presented in Table (4). The average PDs in the sample were calibrated to the means observed as of June 2017. The impact is presented for each income group and split by currency. 
Figure 1. Household Credit Trends

Credit flows to households have risen significantly.

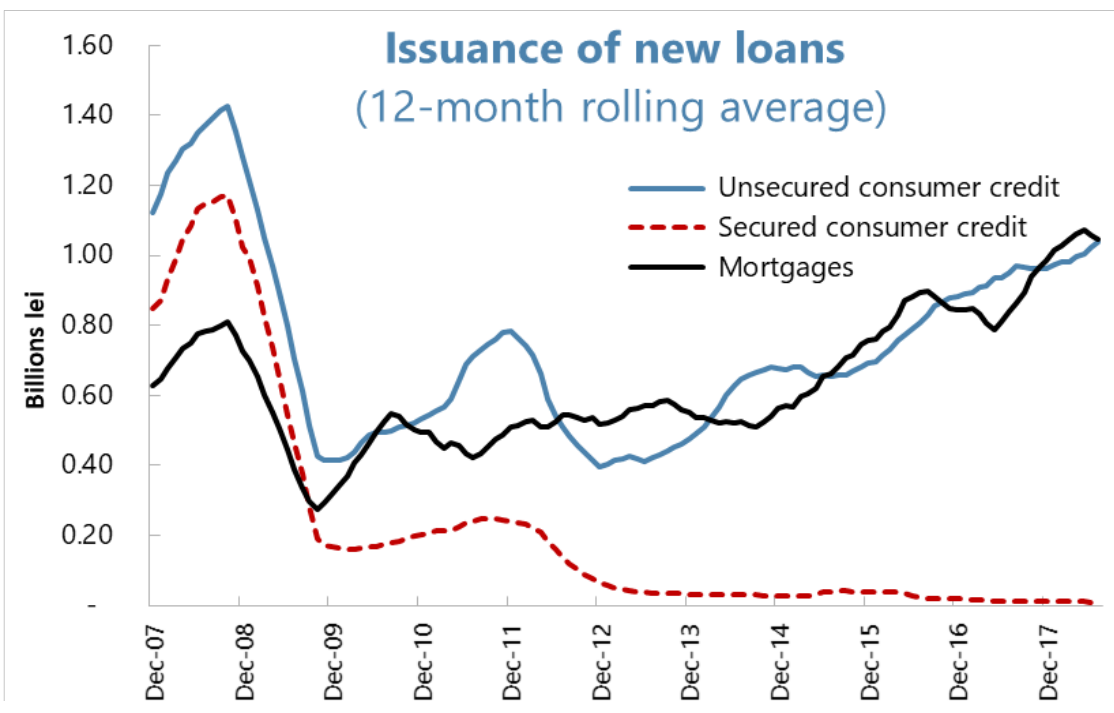

...and credit growth has reached double digits for mortgages.

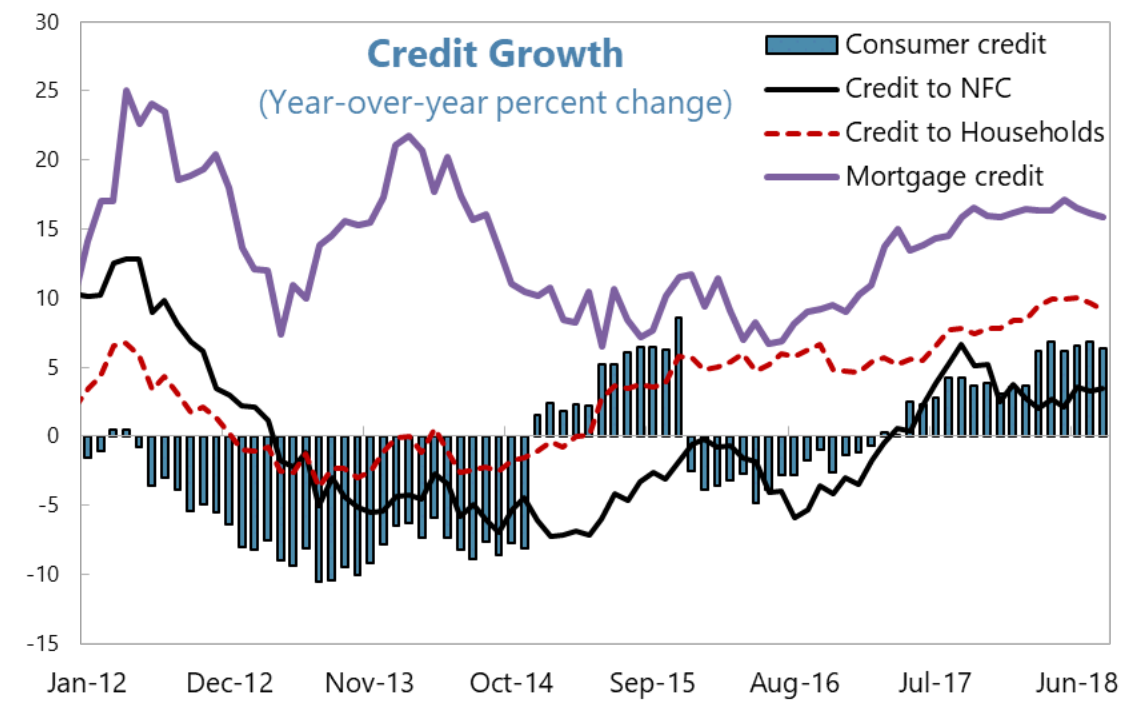

Source: NBR and IMF staff estimates. 
Figure 2. Mortgage Borrower Characteristic

PDs much higher for mortgages originated before The crisis..

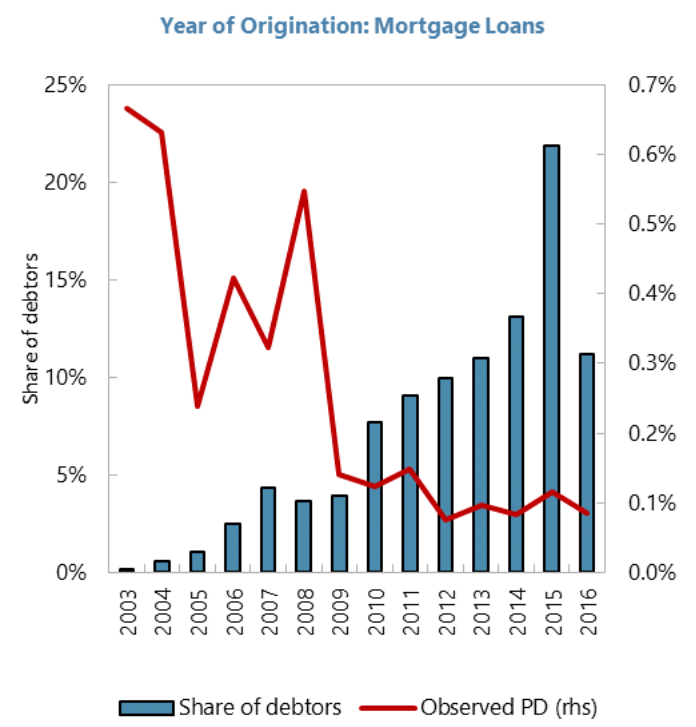

PDs decline with income percentile...

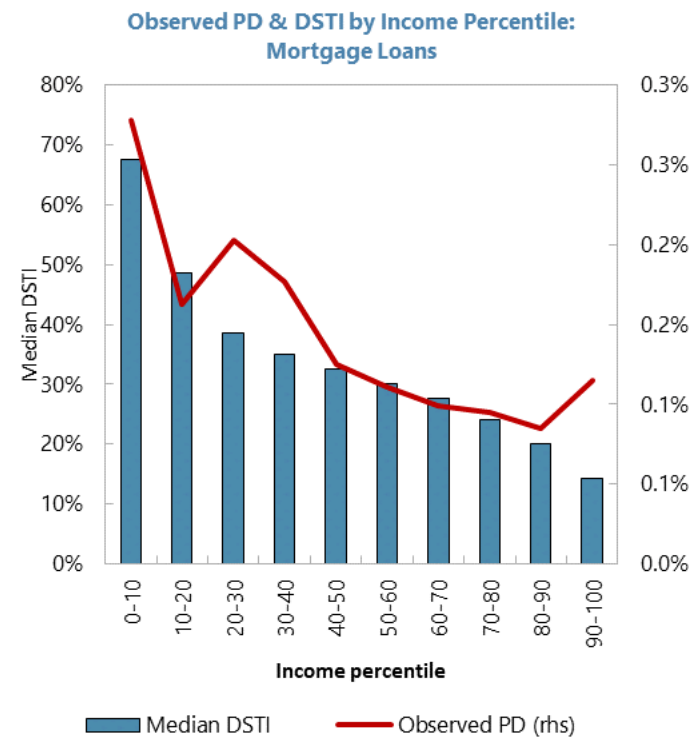

Source: NBR and IMF staff estimates.

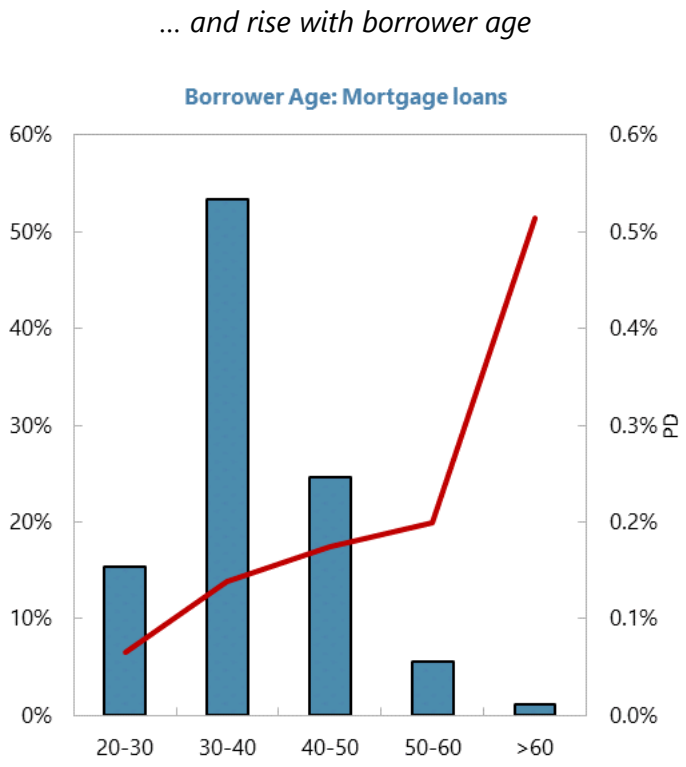

$\square$ Share of debtors $\longrightarrow$ Observed PD (rhs)

... and rise sharply with DSTI.

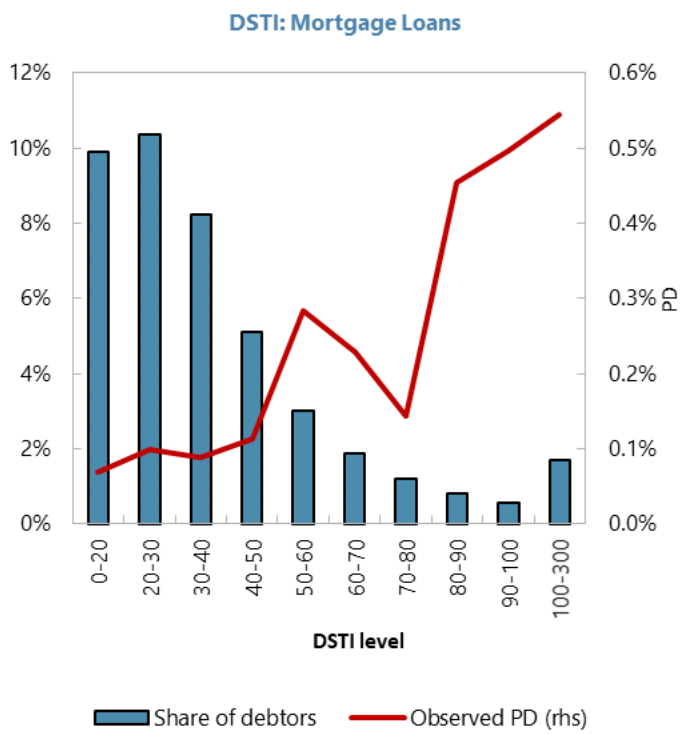


Figure 3. Consumer Loan Borrower Characteristic

Year of origin less important for consumer loans, as maturities are lower than mortgages...

Year of Origination: Consumer Loans

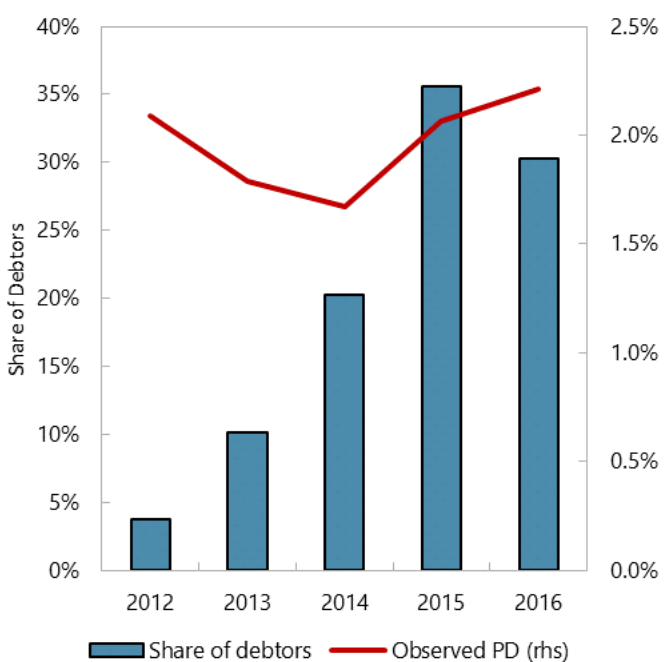

Impact of Income on PDs starker for consumer loans

Observed PD \& DSTI by Income Percentile: Consumer Loans

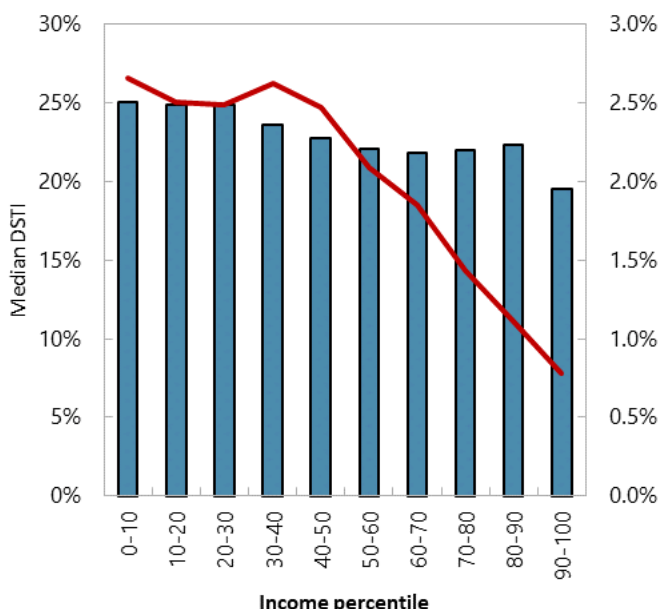

$\square$ Median DSTI

Observed PD (rhs)

Source: NBR and IMF staff estimates.
Average consumer loan borrower is much older...

Borrower Age: Consumer Loans

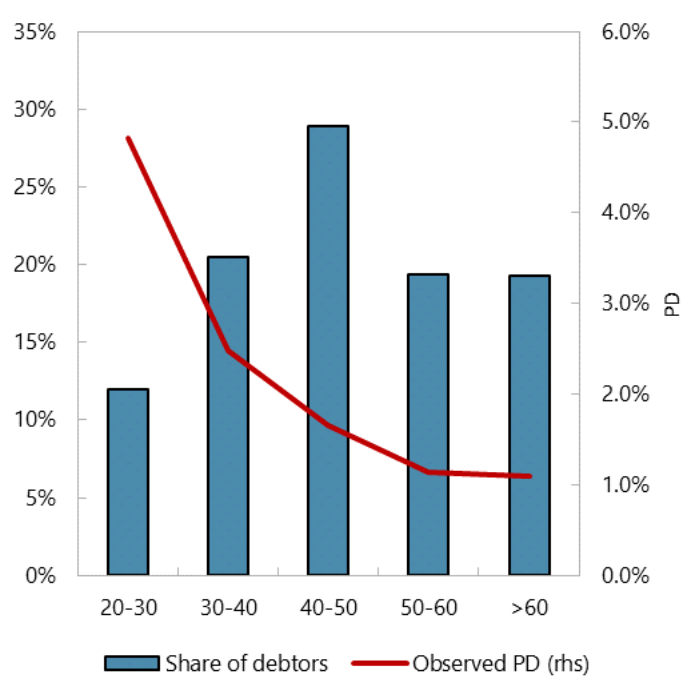

Most consumer loans carry low DSTIs

DSTI: Consumer Loans

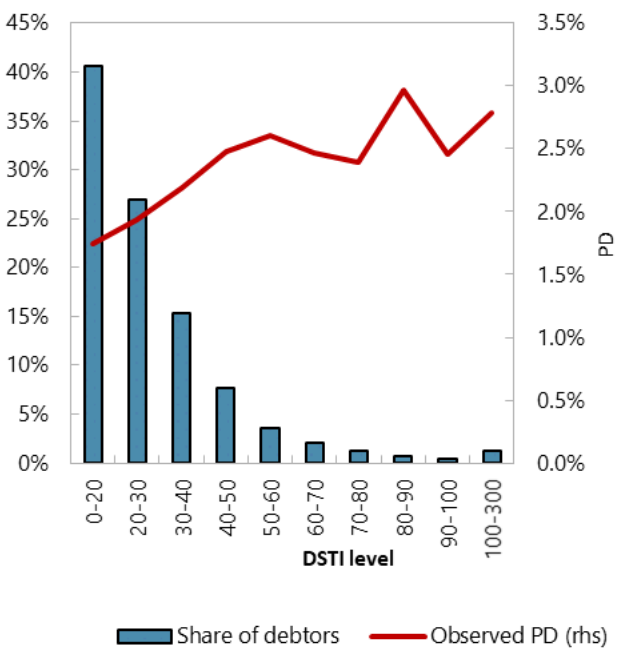


Figure 4. Marginal Impact of DSTI on Probability of Default (PD): Mortgages

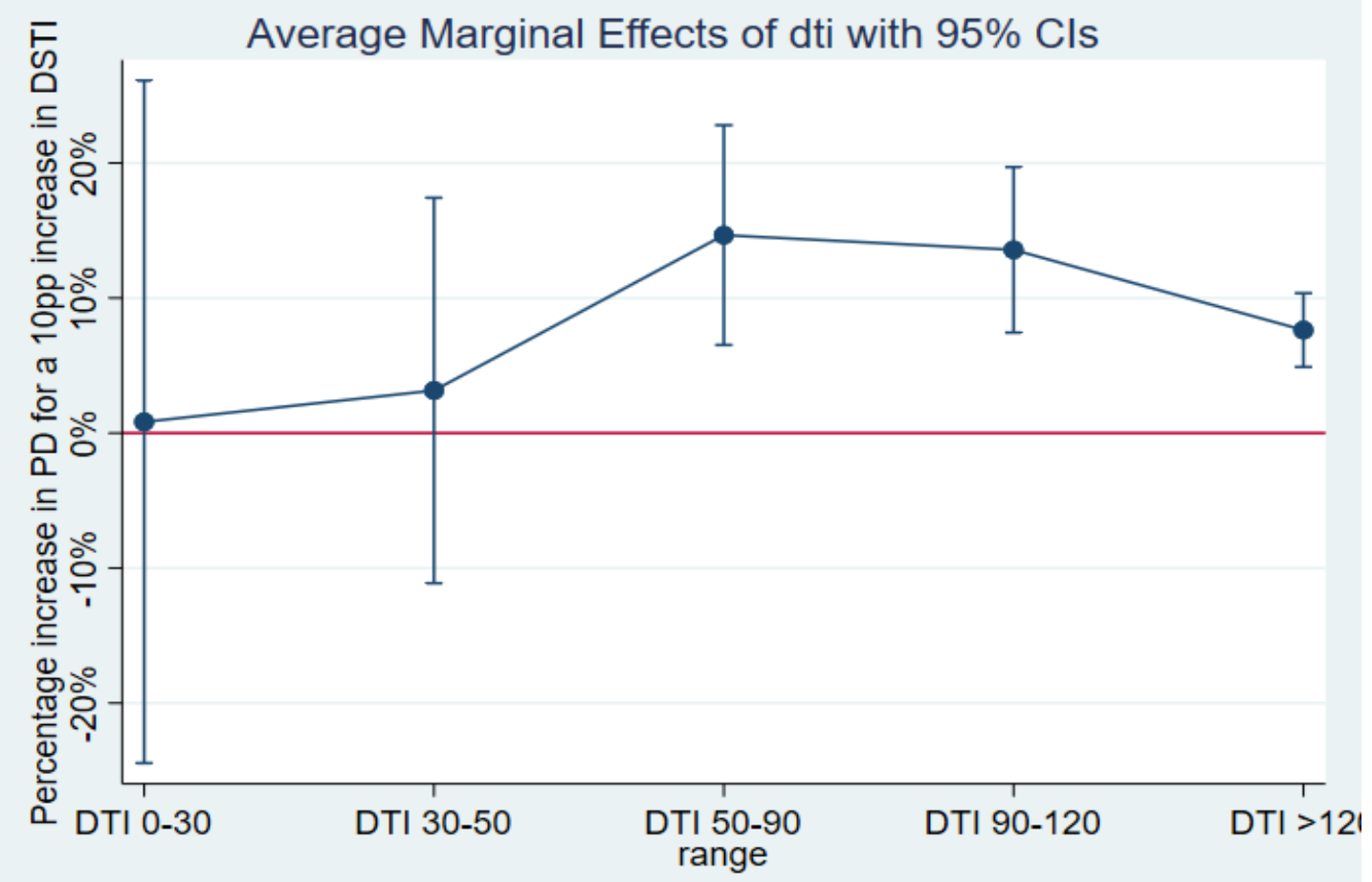

Source: NBR and IMF staff estimates.

Note: The point estimates indicate percentage increase in PD for a 10-percentage point increase in DSTI in the specified range. The bars indicate a 95 percent confidence interval. 
Figure 5. Marginal Impact of DSTI on Probability of Default (PD): Consumer Loans

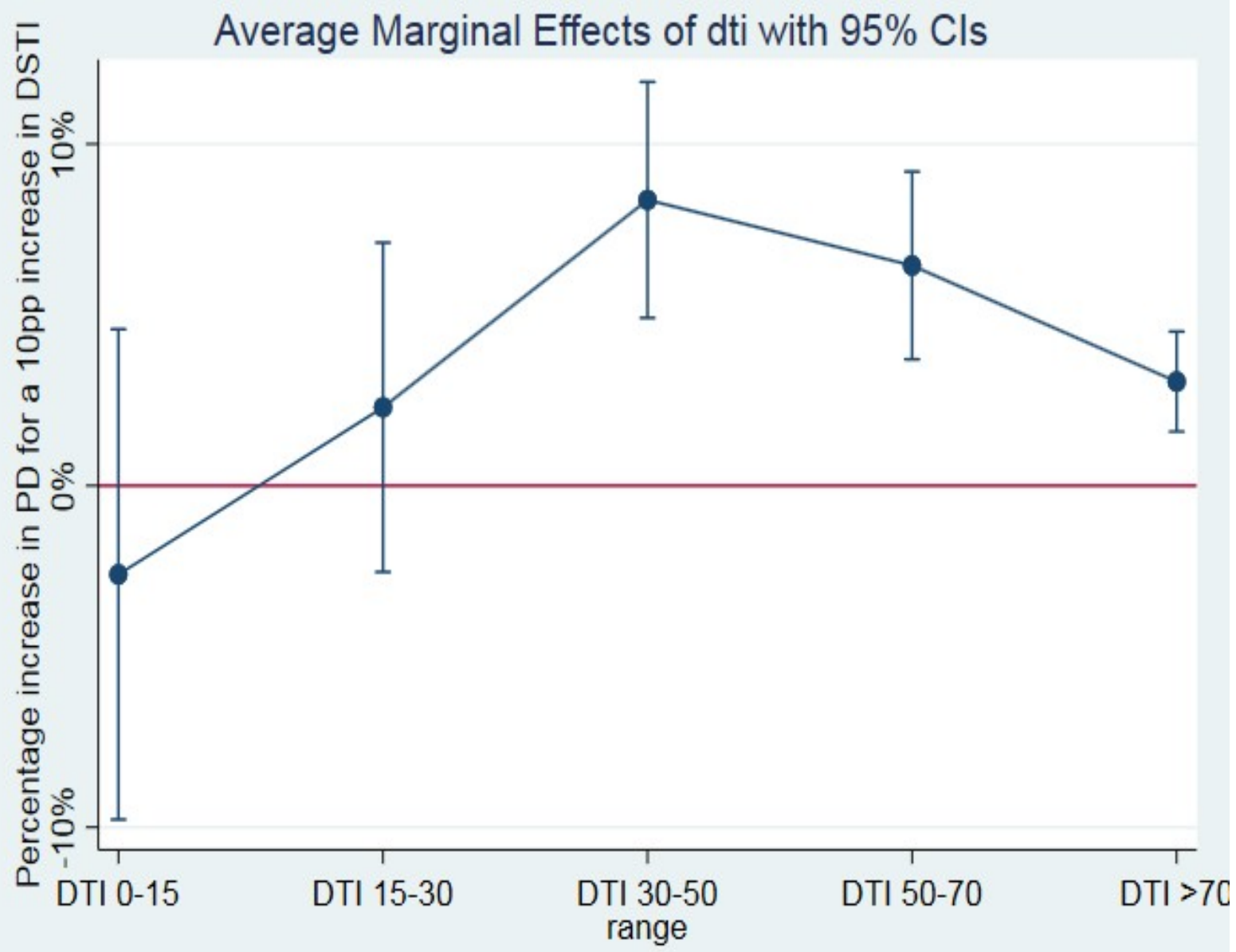

Source: NBR and IMF staff estimates.

Note: The point estimates indicate percentage increase in PD for a 10-percentage point increase in DSTI in the specified range. The bars indicate a 95 percent confidence interval. 


\section{REFERENCES}

Abdul, A., G. Dell’Ariccia, and G. Li, 2011, "Creditless Recoveries,” IMF Working Papers, Vol. 11, No. 58, March.

Acharya, V. V., M. P. Richardson et al, 2009, Restoring Financial Stability: How to Repair a Failed System, Vol. 542: John Wiley \& Sons.

Akinci, O. and J. Olmstead-Rumsey, 2015, How Effective are Macroprudential Policies? An Empirical Investigation, International Finance Discussion Papers 1136, Board of Governors of the Federal Reserve System (U.S.).

Alam, Z., A. Alter, J. Eisemann, G. Gelos, H. Kang, M. Narita, E. Nier, and N. Wang, 2019, "Digging Deeper-Evidence on the Effect of Macroprudential Policies from a New Database,” IMF Working Paper 19/66.

Balás, T., A. Banai, and Z. Hosszú, 2015, "Modelling Probability of Default and Optimal PTI Level by Using a Household Survey,” Acta Oeconomica, Vol. 65, No. 2, pp. 183-209, June.

Claessens, S., S. R. Ghosh, and R. Mihet. 2013. "Macro-Prudential Policies to Mitigate Financial System Vulnerabilities,” Journal of International Money and Finance, Vol. 39, pp. 153-185.

Claessens, S., M. A. Kose, and M. E. Terrones, 2009, "What Happens During Recessions, Crunches and Busts?” Economic Policy, Vol. 24, No. 60, pp. 653-700.

Committee on the Global Financial System, 2016, "Experiences with the Ex-Ante Appraisal of Macroprudential Instruments,” Technical Report.

D'Alessio, G. and S. Iezzi, 2013, Household Over-Indebtedness: Definition and Measurement with Italian Data, February 22, 2013, Bank of Italy Occasional Paper, No. 149.

Epure, M., I. Mihai, C. Minoiu, and J. Peydro. 2017, "House- hold Credit, Global Financial Cycle, and Macroprudential Policies: Credit Register Evidence from an Emerging Country,” Working Papers 1006, Barcelona Graduate School of Economics.

European Systemic Risk Board, 2018, "National Measures of Macroprudential Interest in the EU/EEA,” Technical Report.

Fuster, A. and B. Zafar, 2014, "The Sensitivity of Housing Demand to Financing Conditions: Evidence from a Survey,” Staff Reports 702, Federal Reserve Bank of New York.

Gambacorta, L. and A. Murcia, 2017, “The Impact of Macroprudential Policies and their Interaction with Monetary Policy: An Empirical Analysis Using Credit Registry Data,” BIS Working Papers 636, Bank for International Settlements.

Gross, M. and J. Poblacion, 2017, “Assessing the Efficacy of Borrower-Based Macroprudential Policy Using an Integrated Micro-Macro Model for European Households,” Economic Modelling, Vol. 61, pp. 510-528. 
Igan, D. and H. Kang, 2011, "Do Loan-to-Value and Debt-to-Income Limits Work? Evidence from Korea,” IMF Working Papers, Vol. 11, March.

International Monetary Fund, 2014, “Staff Guidance Note on Macroprudential Policy,” IMF Policy Paper, November.

Jimenez, G., S. Ongena, J.P., and J. Saurina, 2017, “Macro-prudential Policy, Countercyclical Bank Capital Buffers, and Credit Supply: Evidence from the Spanish Dynamic Provisioning Experiments,” Journal of Political Economy, Vol. 125, No. 6. pp. 2126-2177.

Jordà, O., M. Schularick, and A. M. Taylor, 2016, “The Great Mortgaging: Housing Finance, Crises and Business Cycles,” Economic Policy, Vol. 31, No. 85, pp. 107-152.

Kelly, R., T. O’Malley, and C. O’Toole, 2015, “Designing Macroprudential Policy in Mortgage Lending: Do First Time Buyers Default Less?” Research Technical Papers 02/RT/15, Central Bank of Ireland.

King, G. and L. Zeng, 2001, “Logistic Regression in Rare Events Data,” Political Analysis, Vol. 9, No. 2.

Kukk, M, 2016, "What are the Triggers for Arrears on Debt? Evidence from Quarterly Panel Data,” Bank of Estonia Working Papers, WP2016-9, Bank of Estonia.

Kuttner, K. N. and I. Shim, 2016, “Can Non-Interest Rate Policies Stabilize Housing Markets? Evidence from a Panel of 57 Economies,” Journal of Financial Stability, Vol. 26, pp. 31-44.

Maddaloni, A. and J. L. Peydro, 2011, "Bank Risk-Taking, Securitization, Supervision, and low Interest Rates: Evidence from the Euro-Area and the U.S. Lending Standards,” The Review of Financial Studies, Vol. 24, No. 6.

May, O. and M. Tudela, 2005, "When is Mortgage Indebtedness a Financial Burden to British Households? A Dynamic Probit Approach,” Bank of England Working Papers 277, Bank of England.

McCarthy, Y., 2014, "Disentangling the Mortgage Arrears Crisis: The Role of the Labour Market, Income Volatility and Housing Equity,” Research Technical Papers. Central Bank of Ireland.

Mian, A. and A. Sufi, 2009, “The Consequences of Mortgage Credit Expansion: Evidence from the U.S. Mortgage Default Crisis,” The Quarterly Journal of Economics, Vol. 124, No. 4, pp. 1449-1496.

Neagu, F., L. Tatarici, and I. Mihai, 2015, “Implementing Loan- to-Value and Debt ServiceTo-Income Measures: A Decade of Romanian Experience,” Occasional Papers 15, National Bank of Romania.

Reinhart, C. M. and K. S. Rogoff, 2009, “The Aftermath of Financial Crises,” American Economic Review, Vol. 99, No. 2, pp. 466-72. 
Schularick, M. and A. M. Taylor, 2012, "Credit Booms Gone Bust: Monetary Policy, Leverage Cycles, and Financial Crises, 1870-2008,” American Economic Review, Vol. 102, No. 2, pp. 1029-61.

Voinea, L., H. Lovin, and A. Cojocaru, 2018, “The Impact of Inequality on the Transmission of Monetary Policy,” Journal of International Money and Finance, Vol. 85, No. C, pp. 236-250. 